\title{
Snowmelt response to simulated warming across a large elevation gradient, southern Sierra Nevada, California
}

\author{
Keith N. Musselman ${ }^{1, a}$, Noah P. Molotch ${ }^{2,3}$, and Steven A. Margulis ${ }^{4}$ \\ ${ }^{1}$ National Center for Atmospheric Research, Boulder, CO, USA \\ ${ }^{2}$ Department of Geography, Institute of Arctic and Alpine Research, University of Colorado, Boulder, CO, USA \\ ${ }^{3}$ Jet Propulsion Laboratory, California Institute of Technology, Pasadena, CA, USA \\ ${ }^{4}$ Department of Civil and Environmental Engineering, University of California, Los Angeles, CA, USA \\ ${ }^{a}$ now at: Institute of Arctic and Alpine Research, University of Colorado, Boulder, CO, USA
}

Correspondence: Keith N. Musselman (keith.musselman@colorado.edu)

Received: 29 June 2017 - Discussion started: 18 July 2017

Revised: 16 October 2017 - Accepted: 27 October 2017 - Published: 11 December 2017

\begin{abstract}
In a warmer climate, the fraction of annual meltwater produced at high melt rates in mountainous areas is projected to decline due to a contraction of the snow-cover season, causing melt to occur earlier and under lower energy conditions. How snowmelt rates, including extreme events relevant to flood risk, may respond to a range of warming over a mountain front is poorly known. We present a model sensitivity study of snowmelt response to warming across a $3600 \mathrm{~m}$ elevation gradient in the southern Sierra Nevada, USA. A snow model was run for three distinct years and verified against extensive ground observations. To simulate the impact of climate warming on meltwater production, measured meteorological conditions were modified by +1 to $+6^{\circ} \mathrm{C}$. The total annual snow water volume exhibited linear reductions $\left(-10 \%{ }^{\circ} \mathrm{C}^{-1}\right)$ consistent with previous studies. However, the sensitivity of snowmelt rates to successive degrees of warming varied nonlinearly with elevation. Middle elevations and years with more snowfall were prone to the largest reductions in snowmelt rates, with lesser changes simulated at higher elevations. Importantly, simulated warming causes extreme daily snowmelt (99th percentiles) to increase in spatial extent and intensity, and shift from spring to winter. The results offer insight into the sensitivity of mountain snow water resources and how the rate and timing of water availability may change in a warmer climate. The identification of future climate conditions that may increase extreme melt events is needed to address the climate resilience of regional flood control systems.
\end{abstract}

\section{Introduction}

Seasonal snow accumulation and melt in mountainous areas are critical components of the regional hydrologic cycle with important controls on climate, ecosystem function, flood risk, and water resources (Bales et al., 2006; Barnett et al., 2005). Warmer temperatures are expected to reduce snowpack volume and persistence (Gleick, 1987; Knowles and Cayan, 2004; Mote et al., 2005) by shifting precipitation from snowfall to rain (Knowles et al., 2006) and causing earlier snowmelt (Stewart et al., 2004). Studies of historical observations in the western USA have identified recent declines in spring snowpack (Mote et al., 2005), diminished snowmelt runoff volumes (Dettinger and Cayan, 1995; McCabe and Clark, 2005), and earlier spring runoff (Stewart et al., 2004). Most of these studies have attributed the observed trends to anomalously warm spring and summer temperatures of recent decades. Fyfe et al. (2017) report that the recent snowpack declines are not replicable with climate model simulations forced by natural changes alone, but are resolved when both natural and anthropogenic changes are considered.

Continued warming is expected. General circulation models (GCMs) project increases in global average temperatures ranging from $0.7^{\circ} \mathrm{C} \pm 0.4^{\circ} \mathrm{C}$ to $6.5^{\circ} \mathrm{C} \pm 2.0^{\circ} \mathrm{C}$ for the lowest and highest greenhouse gas emission scenarios, respectively, for the end of the next century (Stocker et al., 2013). The effects of a warmer climate on the snow-dominated hydrology of the Sierra Nevada, for example, are generally recognized to include higher winter storm runoff and flood risk, and reduced summer low flows (Dettinger, 2011; Dettinger 
et al., 2004; Godsey et al., 2013; Knowles and Cayan, 2002; Lettenmaier and Gan, 1990). It is not well understood how present-day snowmelt rates may respond to the range of projected warmer temperature scenarios and, particularly, how those changes will impact water availability over large elevation gradients.

Elevation is a dominant explanatory variable of mountain snow-cover persistence (Girotto et al., 2014b), ranking in importance above solar radiation and terrain aspect for many basins in the western USA (Molotch and Meromy, 2014). Snowpack response to warmer temperatures exhibits strong nonlinear elevation dependencies (Brown and Mote, 2009; Knowles and Cayan, 2004). For example, slight warming can cause drastic hydrologic response at lower elevations as rain becomes the predominant hydrologic input and snow cover becomes seasonally intermittent or negligible (Hunsaker et al., 2012; Marty et al., 2017; Nolin and Daly, 2006). At higher and cooler elevations, snowmelt may remain a substantial component of the annual hydrologic input in a warmer climate, but the timing and rate of melt are altered. Rapid and prolonged spring snowmelt is unique to these mountain environments (Trujillo and Molotch, 2014). This efficient runoff generation mechanism (Barnhart et al., 2016) produces water resources of vast economic importance (Sturm et al., 2017). Improved understanding of regional elevation-dependent snowmelt response to warming is a key step toward better predicting and interpreting model estimates of basin-wide runoff.

In a warmer climate, the fraction of meltwater produced at high melt rates is projected to decrease due to a contraction of the historical melt season to a period of lower available energy (Musselman et al., 2017). Because streamflow is a nonlinear response to hydrologic input, slight reductions in snowmelt rates may disproportionately reduce runoff. Despite recent advances in process understanding, the sensitivity of snowmelt rates to a range of potential warming over a foothills-to-headwaters elevation profile remains poorly known. The topic is a key determinant of changes in how precipitation is partitioned amongst soil storage, evapotranspiration, and runoff, with implications for ecological response (Tague and Peng, 2013; Trujillo et al., 2012) and regional water resources (Gleick and Chalecki, 1999; Vano et al., 2014).

We present a climate sensitivity experiment to investigate how carefully verified model simulations of historical snow water equivalent (SWE) and melt rates respond to successively warmer temperatures that span the range of projected wintertime warming over western North America for this century (Van Oldenborgh et al., 2013). A controlled experiment with a physically based snow model promotes a detailed analysis of the following research questions: (1) how do SWE and snowmelt rates vary with elevation and how do those gradients vary amongst dry, average, and wet snow seasons? (2) How do historical SWE and snowmelt rates respond to successive degrees of warming?

\section{Methods}

To evaluate the response of SWE and snowmelt dynamics to warmer temperatures, we conduct a reanalysis of historical snow seasons using the physically based Alpine3D (Lehning et al., 2006) snow model run at $100 \mathrm{~m}$ grid spacing over a mountainous region spanning a $3600 \mathrm{~m}$ elevation gradient in the southern Sierra Nevada, California. Snowpack simulations for three historical snow seasons were first verified against multi-scale, ground-based observations. Simulated snowpack characteristics over discrete elevation bands were then examined for their sensitivity to warmer conditions using a delta-change approach in which observed air temperature values and the longwave radiative equivalent were augmented by +1 to $+6^{\circ} \mathrm{C}$ in $+1{ }^{\circ} \mathrm{C}$ increments. Given the relatively small $(<10 \%)$ precipitation changes projected for central and southern California (Cayan et al., 2008), and a lack of agreement of climate models on the sign of projected precipitation changes (Seager et al., 2013), the focus of the current study is on the snowpack response to simulated warming rather than combined changes in temperature and precipitation. Sensitivity was examined for three historical snow years representative of the climatological range in snowfall (years with below-average, average, and above-average snowfall), snow-cover duration, and precipitation timing. The following sub-sections describe the details of our model experiment, verification, and analysis methods.

\subsection{Study domain}

The study was conducted over a $1648 \mathrm{~km}^{2}$ area encompassing the $1085 \mathrm{~km}^{2}$ Kaweah River basin on the western slope of the southern Sierra Nevada, California, USA $\left(36.4^{\circ} \mathrm{N}, 118.6^{\circ} \mathrm{W}\right.$; Fig. 1). The elevation of the Kaweah River basin ranges from $250 \mathrm{~m}$ to over $3800 \mathrm{~m}$ a.s.l. The landcover and climate of the domain vary substantially over the full $3633 \mathrm{~m}$ elevation range (Fig. 1). Approximately $98 \%$ of the domain is comprised of four land-cover types (Fry et al., 2011): conifer forest (58\%), shrub (26\%), bare soil/rock $(10 \%)$, and grass/tundra (4\%; Fig. 1). A mix of grassland, shrub, and oak woodlands characterizes the vegetation of the low-elevation foothills $(<1600 \mathrm{~m}$ a.s.1.), where mild and wet winters and arid summers characterize the climate and a $660 \mathrm{~mm}$ average annual precipitation is rain-dominated (National Park Service, 2017). At middle elevations (1600 m to $3000 \mathrm{~m}$ a.s.1.), mixed conifer forest stands are dominant, including some of the world's only giant sequoia (Sequoiadendron giganteum) groves. The middle elevation climate is cool with seasonally snow-covered winters and warm, dry summers, and the average annual precipitation exceeds $1080 \mathrm{~mm}$ (NPS, 2017). Forest vegetation of the sub-alpine zone, between 3000 and $3500 \mathrm{~m}$ a.s.l., is sparse and coniferous. Precipitation is not measured at these upper elevations. At the highest elevations (> $3500 \mathrm{~m}$ a.s.l.), the land cover is bedrock 

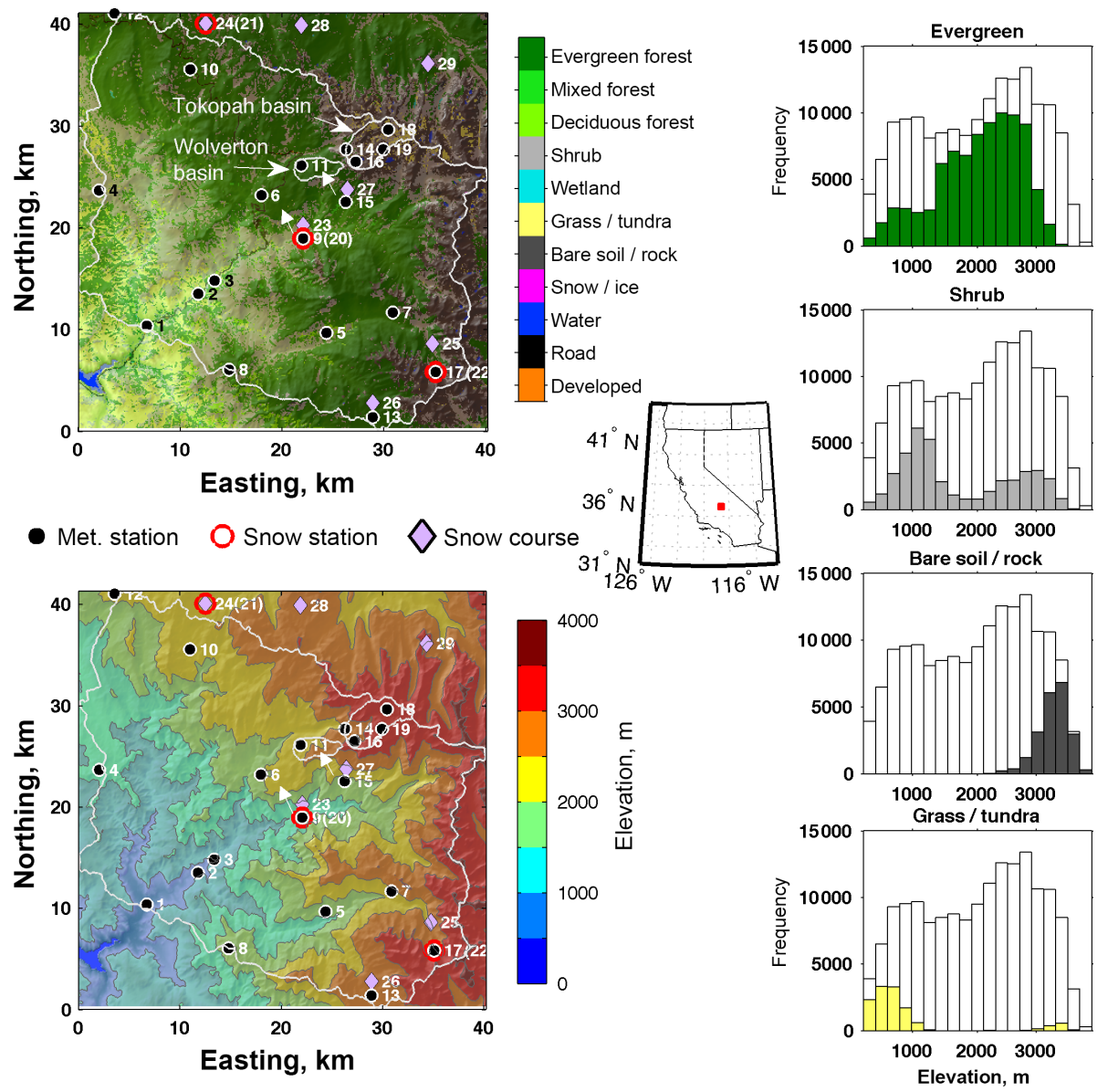

Figure 1. The elevation and land cover distribution of the model domain encompassing the Kaweah River basin (outlined) on the western side of the southern Sierra Nevada, California. Locations of the forested Wolverton and largely alpine Tokopah research basins are indicated. The locations of 19 automated meteorological stations (filled circle markers), three automated snow stations (red circles), and seven monthly snow survey transects (diamond markers) are shown. Station numbers correspond to those in Table 1. The histograms illustrate the elevation distribution of the four primary land cover types (colored bars) relative to the elevation of the model domain (empty bars).

with sparse alpine vegetation and snow cover typically persists from November to July.

The domain includes two research basins: the $7.22 \mathrm{~km}^{2}$ forested Wolverton basin and the $19.1 \mathrm{~km}^{2}$ largely alpine Tokopah basin (Fig. 1). The Wolverton basin is representative of regional forested mid-elevations. A detailed description of the Wolverton basin instrumentation is provided in Musselman et al. (2012b). The $19.1 \mathrm{~km}^{2}$ Tokopah basin is representative of regional small headwater basins (Tonnessen, 1991). It is instrumented with numerous meteorological stations and has been the subject of many studies on snow distribution (Elder et al., 1988; Girotto et al., 2014a; Jepsen et al., 2012; Marks et al., 1992; Molotch et al., 2005) and biogeochemistry (Perrot et al., 2014; Sickman et al., 2003; Williams and Melack, 1991). We use ground-based observations from these research basins to verify the model as described in Sect. 2.4.

\subsection{Snow model}

Alpine3D (Lehning et al., 2006) is a land surface model with an emphasis on snow process representation. It has been used in previous snow process studies (Bavay et al., 2009; Magnusson et al., 2011; Michlmayr et al., 2008; Mott et al., 2008) and projections of future snow or runoff (e.g., Bavay et al., 2009, 2013; Kobierska et al., 2011, 2013; Marty et al., 2017). At the core of Alpine3D is the one-dimensional SNOWPACK model (Bartelt and Lehning, 2002), which has been validated in alpine (e.g., Etchevers et al., 2004) and forested (e.g., Rutter et al., 2009) environments, including a previous study in the Wolverton basin using a subset of the forcing and verification data presented herein (Musselman et al., 2012a). At each model grid cell, mass and energy balance equations for vegetation, snow, and soil columns are solved with external forcing provided by the atmospheric variables described in Sect. 2.3. The physically based model system was uncal- 
Table 1. Meteorological station and snow measurement details. Station numbers are ranked by station elevation and correspond to those mapped in Fig. 1. The variables measured at each location are listed: air temperature $\left(T_{\mathrm{a}}\right)$, relative humidity (RH), wind speed (ws), precipitation (ppt), snow water equivalent (SWE), and snow depth (depth).

\begin{tabular}{|c|c|c|c|c|}
\hline No. & Station name & Elev., m & Measured variables* & Operating agency** \\
\hline \multicolumn{5}{|c|}{ Automated met. stations } \\
\hline 1 & D0117 & 263 & $T_{\mathrm{a}}, \mathrm{RH}, \mathrm{ws}$ & APRSWXNET \\
\hline 2 & C4177 & 378 & $T_{\mathrm{a}}, \mathrm{RH}, \mathrm{ws}$ & APRSWXNET \\
\hline 3 & Ash Mountain & 527 & $T_{\mathrm{a}}, \mathrm{RH}, \mathrm{ws}, \mathrm{ppt}$ & NPS \\
\hline 4 & Shadequarter & 1323 & $T_{\mathrm{a}}, \mathrm{RH}, \mathrm{ws}$ & $\mathrm{CDF}$ \\
\hline 5 & Wolverton & 1598 & $T_{\mathrm{a}}, \mathrm{RH}, \mathrm{ws}$ & NPS \\
\hline 6 & Lower Kaweah & 1926 & $T_{\mathrm{a}}, \mathrm{RH}, \mathrm{ws}, \mathrm{ppt}$ & NPS \\
\hline 7 & Atwell & 1951 & ppt & USACE \\
\hline 8 & Case Mountain & 1967 & $T_{\mathrm{a}}, \mathrm{RH}, \mathrm{ws}$ & BLM \\
\hline 9 & Giant Forest & 2027 & $T_{\mathrm{a}}, \mathrm{ppt}$ & USACE \\
\hline 10 & Bear Trap Meadow & 2073 & ppt & USACE \\
\hline 11 & Wolverton Meadow & 2229 & $T_{\mathrm{a}}, \mathrm{RH}, \mathrm{ws}$ & SNRI \\
\hline 12 & Park Ridge & 2299 & $T_{\mathrm{a}}, \mathrm{RH}, \mathrm{ws}$ & NPS \\
\hline 13 & Hockett Meadows & 2592 & ppt & USACE \\
\hline 14 & Marble Fork & 2626 & $T_{\mathrm{a}}$ & ERI \\
\hline 15 & Panther Meadow & 2640 & $T_{\mathrm{a}}, \mathrm{RH}, \mathrm{ws}$ & SNRI \\
\hline 16 & Emerald Lake & 2835 & $T_{\mathrm{a}}, \mathrm{RH}, \mathrm{ws}$ & ERI \\
\hline 17 & Farewell Gap & 2896 & $T_{\mathrm{a}}$ & USACE \\
\hline 18 & Topaz Lake & 3232 & $T_{\mathrm{a}}, \mathrm{RH}, \mathrm{ws}, \mathrm{SW}, \mathrm{LW}$ & ERI \\
\hline 19 & M3 & 3288 & $T_{\mathrm{a}}, \mathrm{RH}, \mathrm{ws}$ & ERI \\
\hline \multicolumn{5}{|c|}{ Automated snow stations } \\
\hline 20 & Giant Forest & 1951 & SWE & USACE \\
\hline 21 & Big Meadows & 2317 & SWE & USACE \\
\hline 22 & Farewell Gap & 2896 & SWE, depth & USACE \\
\hline \multicolumn{5}{|c|}{ Monthly snow courses } \\
\hline 23 & Giant Forest & 1951 & SWE, depth & NPS \\
\hline 24 & Big Meadows & 2317 & SWE, depth & CADWP \\
\hline 25 & Mineral King & 2439 & SWE, depth & NPS \\
\hline 26 & Hockett Meadow & 2592 & SWE, depth & NPS \\
\hline 27 & Panther Meadow & 2622 & SWE, depth & NPS \\
\hline 28 & Rowell Meadow & 2698 & SWE, depth & KRWA \\
\hline 29 & Scenic Meadow & 2942 & SWE, depth & KRWA \\
\hline
\end{tabular}

* Meteorological variables used in this study.

* Agency abbreviations: APRSWXNET: Automatic Position Reporting System as a Weather NETwork; NPS National Park Service (Sequoia and Kings Canyon National Parks); CDF: California Department of Forestry; USACE: United States Army Corps of Engineers; BLM: Bureau of Land Management; SNRI: Sierra Nevada Research Institute, University of California Merced; ERI: Earth Research Institute, University of California Santa Barbara; CADWP: California Department of Water and Power; KRWA: Kaweah River Water Association.

ibrated. Model decisions and parameters were chosen based on their successful application in previous studies.

The bottom (soil) boundary conditions were treated with a constant geothermal heat flux of $0.06 \mathrm{~W} \mathrm{~m}^{-2}$ applied at the base of a six-layer soil module (see Musselman et al., 2012a). In the case of vegetation cover, the surface-atmosphere boundary conditions were solved for in a single-layer canopy module (Musselman et al., 2012a). Wind transport of snow is not considered in this model implementation. New-snow density and snow albedo parameterizations used in previous studies in the European Alps (Bavay et al., 2013) were found to work well in the Wolverton basin (Musselman et al., 2012a) and are used in the current study. Other land-cover parameters such as canopy height and leaf area index were specified according to land-cover classifications discussed in Sect. 2.3. A simple $1.2^{\circ} \mathrm{C}$ air temperature threshold was used to distinguish rain from snow, slightly higher than the $1.0^{\circ} \mathrm{C}$ value used in Musselman et al. (2012a). 


\subsection{Model input data}

\subsubsection{Topography and land-cover data}

The elevation and land-cover across the domain were represented at $100 \mathrm{~m}$ grid spacing. Land-cover classification (Fig. 1) was specified from the National Land Cover Database (NLCD; Fry et al., 2011). In addition to the landcover classes listed in Fig. 1, forest-covered grid cells were aggregated into coniferous, mixed, and deciduous categories based on the dominant species within each cell. The NLCD canopy density values, used to parameterize canopy snow interception and snow surface energy fluxes, were binned from 5 to $85 \%$ in $10 \%$ intervals. Grid elements containing vegetation were specified to have an effective leaf area index and canopy height, respectively, of $0.5 \mathrm{~m}^{2} \mathrm{~m}^{-2}$ and $1.5 \mathrm{~m}$ for shrub/chaparral, $1.2 \mathrm{~m}^{2} \mathrm{~m}^{-2}$ and $20 \mathrm{~m}$ for deciduous, $2.0 \mathrm{~m}^{2} \mathrm{~m}^{-2}$ and $30 \mathrm{~m}$ for mixed, and $2.7 \mathrm{~m}^{2} \mathrm{~m}^{-2}$ and $40 \mathrm{~m}$ for coniferous forests.

\subsubsection{Meteorological data}

Hourly meteorological observations were available from 19 stations within the domain (Fig. 1 and Table 1). Sixteen stations recorded hourly air temperature and six reported precipitation (Table 1). The Ash Mountain station at $527 \mathrm{~m}$ a.s.1. provided the only low-elevation precipitation measurements. The Lower Kaweah, Atwell, Giant Forest, and Bear Trap Meadow stations are located within a narrow elevation band of 1926 to $2073 \mathrm{~m}$ a.s.l. (Fig. 1 and Table 1). Data from a single higher station (Hockett Meadow; 2592 ma.s.l.) were not used because of gauge error for the time period of interest. Precipitation gauge catch efficiency was specified as 0.95 for rain and 0.6 for snow, using the $1.2^{\circ} \mathrm{C}$ air temperature threshold as a determinant of precipitation phase. Incoming shortwave radiation was provided from the Topaz Lake meteorological station (Fig. 1; Table 1). The direct beam was adjusted for grid-cell-specific terrain shading and elevation dependency and the diffuse component was assumed spatially uniform for each time step (see Bavay et al., 2013 for details). The shortwave radiation data are well correlated with measurements at middle elevations (Musselman et al., 2012b) and are used to model the full domain.

The remaining meteorological variables required spatial interpolation from station locations to all grid cells. Because elevation can have a profound influence on many of the meteorological variables, several of the interpolation methods used linear elevation trends. Interpolations were conducted with the data access and pre-processing library MeteoIO (Bavay and Egger, 2014) and computed with an inverse distance weighting (IDW) algorithm with elevation lapse rate adjustments for air temperature, wind speed, and precipitation. Lapse rates were computed for each hourly time step using a regression technique (Bavay and Egger, 2014) applied to observations from all available stations. If the correlation coefficient was less than 0.6 , then a constant elevation lapse rate of $-0.008^{\circ} \mathrm{C} \mathrm{m}^{-1}$ was used for air temperature, and a standardized elevation trend of $0.0006 \mathrm{~m}^{-1}$ was used for precipitation. The incoming longwave radiation measured at the Topaz Lake station was distributed to all grid cells with a constant elevation lapse rate of $-0.03125 \mathrm{~W} \mathrm{~m}^{-2} \mathrm{~m}^{-1}$ as in Bavay et al. (2013). Relative humidity was interpolated as in Liston and Elder (2006). The sensitivity of Alpine3D results to meteorological interpolation and model decisions are addressed in Schlögl et al. (2016).

\subsection{Snow observations and validation data}

\subsubsection{Seasonal basin-scale snow surveys}

Snow surveys were conducted in the two research basins for three snow seasons: 2008, 2009, and 2010. Three snow surveys of the forested Wolverton basin were conducted each in 2008 and 2009. The survey timing coincided with periods of accumulation (mid-February), maximum accumulation (mid-March), and melt (late April). In all three years, early April surveys of the alpine Tokopah basin were conducted. In 2009, two additional Tokopah basin surveys captured accumulation (early March) and melt (mid-May). Surveys were conducted with graduated probes to measure snow depth at waypoint locations on a $250 \mathrm{~m}$ grid. Surveyors navigated to the waypoints using GPS units. At each waypoint, three snow depth measurements separated by $5 \mathrm{~m}$ were made along a north-south axis. In total over the 3 years, 1494 waypoints were surveyed. During each survey, snow density was recorded from snow pits conducted at lower and upper elevations to capture the basin range of snow density; only one snow pit was dug during the 2010 Tokopah survey. An undisturbed snow face was excavated to ground and snow density in duplicate columns was measured in $10 \mathrm{~cm}$ vertical intervals by weighing snow samples acquired with a $1000 \mathrm{~cm}^{3}$ cutter. In total, 26 snow pits were measured over the 3 years. The average snow density at all pits made during a survey was used to estimate SWE at waypoint locations, which represent the average of three depth measurements. This approach assumes that basin-scale snow density varies less than snow depth (López-Moreno et al., 2013).

Simulated SWE at model grid elements containing waypoint positions are evaluated against the snow survey values. Three model evaluation metrics are reported. The model bias is computed as the average difference ("modeled minus measured") of $n$ survey measurements for each waypoint measurement $\mathrm{SWE}_{o_{i}}$ and corresponding model grid cell $\mathrm{SWE}_{m_{i}}$. The root-mean-square error (RMSE) is computed as

$$
\mathrm{RMSE}=\sqrt{\frac{1}{n} \sum_{i=1}^{n}\left(\mathrm{SWE}_{m_{i}}-\mathrm{SWE}_{o_{i}}\right)^{2}},
$$


and the normalized mean square error (NMSE) value is computed as

$\mathrm{NMSE}=\frac{\overline{\left(\mathrm{SWE}_{m}-\mathrm{SWE}_{o}\right)^{2}}}{\overline{\mathrm{SWE}_{m}} \overline{\mathrm{SWE}_{o}}}$,

where the over bars denote the mean over all waypoint locations. The NMSE metric facilitates model performance comparisons amongst basins, months, and years.

\subsubsection{Monthly plot-scale snow surveys}

Monthly (1 February-1 May) manual SWE measurements in the Sierra Nevada are made by the California Cooperative Snow Survey (CCSS) program to monitor regional water resources. Seven snow course sites are located within the study domain (Table 1); the sites range in elevation from 1951 to 2942 m. At each snow course, linear transects of approximately 10 SWE measurements made with Federal snow tube samplers are averaged to represent the mean SWE over a distance similar to the $100 \mathrm{~m}$ grid cell spacing. The survey measurements thus provide a SWE estimate that is arguably more representative of the average value within a corresponding model grid cell than the three point-measurements of the basin-scale surveys or a single automated SWE station measurement. Modeled SWE values for each survey date at the grid cells corresponding to each snow course location were evaluated against measured values.

\subsubsection{Automated snow depth sensor network}

In addition to the repeated basin- and plot-scale manual snow surveys, the Wolverton basin includes a network of 24 ultrasonic snow depth sensors. Four research sites at different elevations (2253, 2300, 2620, and $2665 \mathrm{~m}$ a.s.1.) each include six snow depth sensors and each site falls within a different $100 \mathrm{~m} \times 100 \mathrm{~m}$ model grid cell. The range of snow depth measured at the six sensors provides a robust estimate of the snow depth, and thus model skill, at four grid cells spanning slope, aspect, forest density, and elevation in the basin.

\subsubsection{Automated SWE stations}

Daily SWE observations were available from three CCSS automated stations (i.e., snow "pillows") at middle elevations: Giant Forest (1951 ma.s.1.), Big Meadows (2317 ma.s.1.), and Farewell Gap (2896 m; Table 1 and Fig. 1). Modeled SWE fields were evaluated against these station observations using the RMSE and bias metrics described above. The climatological mean SWE record (26 years at Giant Forest and Big Meadows; 15 years at Farewell Gap) was used to evaluate how the three snow seasons studied here compare to the long-term average.

\subsection{Experimental design}

The model was run to simulate seasonal snow dynamics for three reference water years (1 October 2007-30 September 2010) for which the extensive ground-based observations were available. Model estimates of snow depth and SWE were evaluated against the observations.

Six warmer temperature scenarios for each of the three reference years were simulated by increasing the hourly measured air temperature from the 19 regional meteorological stations by +1 to $+6{ }^{\circ} \mathrm{C}$ in $1^{\circ} \mathrm{C}$ increments. The lower $\left(+1^{\circ} \mathrm{C}\right)$ and upper $\left(+6^{\circ} \mathrm{C}\right)$ limits of simulated warming correspond to the average winter air temperature increases projected for the year 2100 in western North America in the Representative Concentration Pathway (RCP) emissions scenarios 2.6 (lowest emissions) and 8.5 (highest emissions), respectively (see top-right panel in Fig. A1.16 in Van Oldenborgh et al., 2013). For each warmer temperature scenario $\left(+n{ }^{\circ} \mathrm{C}\right)$ and hourly time step $(t)$, the incoming longwave radiation $\mathrm{LW}_{\downarrow t}\left(\mathrm{~W} \mathrm{~m}^{-2}\right)$ measured at the Topaz Lake station was adjusted for the increase in effective radiative temperature resulting from the warmer air. The in situ atmospheric emissivity $\epsilon_{t}$ was estimated from the hourly air temperature $T_{\mathrm{a}_{t}}\left({ }^{\circ} \mathrm{C}\right)$ :

$\epsilon_{t}=\frac{\mathrm{LW}_{\downarrow t}}{\sigma\left(T_{\mathrm{a}_{t}}+273.15\right)^{4}}$,

where $\sigma$ is the Stefan-Boltzmann constant $(5.670373 \times$ $\left.10^{-8} \mathrm{~W} \mathrm{~m}^{-2} \mathrm{~K}^{-4}\right)$. The longwave radiation was adjusted for an effective radiative temperature increase of $n\left({ }^{\circ} \mathrm{C}\right)$ as

$\mathrm{LW}_{\downarrow t_{\left(T_{\mathrm{a}}+n\right)}}=\epsilon_{t} \sigma\left(T_{\mathrm{a}_{t}}+273.15+n\right)^{4}$.

Relative humidity was held constant to allow water vapor pressure to vary in a manner consistent with the ideal gas law (Rasouli et al., 2015). The in situ atmospheric emissivity is assumed to be constant for the perturbed temperature scenarios. A lack of clear projected wintertime precipitation response to climate change in the southern Sierra Nevada (see Fig. A1.18 in Van Oldenborgh et al., 2013) prompted our focus on temperature sensitivity rather than a combination of temperature and precipitation. Observed and adjusted meteorological variables representative of the warmer scenarios were interpolated to domain grid cells as described in Sect. 2.3.2. The model was run as in the reference scenarios (Sect. 2.2).

Daily maps of simulated SWE, snow depth, and sublimation were output for each of the three reference years and six temperature perturbations (21 simulations). For each simulation, we evaluate the elevational distribution of SWE ( $\mathrm{mm})$, daily melt (mm day $\left.{ }^{-1}\right)$, and total annual melt reported as the depth per unit area (mm per $100 \mathrm{~m}$ grid cell) and the total volume $\left(\mathrm{km}^{3}\right)$. The daily depletion of SWE, less the daily atmospheric exchange with the snow surface (i.e., sublimation and accretion of ice), is a first-order estimate of daily 
snowmelt (hereafter, snowmelt rate). The total annual meltwater is then the annual sum of daily snowmelt.

To evaluate how SWE and melt in each scenario varied with elevation, metrics were averaged or summed into 200 elevation bands, each encompassing $\sim 18$ vertical meters, with a mean of 823 grid cells per elevation band (maximum of 1412). Rice et al. (2011) found that snow disappearance in the Sierra Nevada occurred 20 days later for each $300 \mathrm{~m}$ rise in elevation. The $18 \mathrm{~m}$ elevation discretization captures this variability at approximately 1 day per elevation band. For each warmer scenario, the total annual meltwater volume is reported as the fraction of that simulated in the nominal (i.e., unperturbed) case. For all scenarios, we report the annual meltwater in three ways: the average meltwater volume and melt rate within each elevation band, the sum of annual meltwater within each elevation band, and the total annual meltwater summed over the entire model domain. The sensitivity of total domain-wide annual meltwater to simulated warming is examined with a (linear) regression analysis of the fraction of historical total meltwater for each warmer scenario of the three years.

To evaluate the effect of simulated warming on melt rates over the elevation profile for the three years, we report the elevation-specific mean fraction of total annual meltwater produced at high $\left(\geq 15 \mathrm{mmday}^{-1}\right)$ melt rates, reported as a percent change relative to the nominal case. The $15 \mathrm{~mm}$ day $^{-1}$ threshold was selected as a compromise between the $12.5 \mathrm{~mm} \mathrm{day}^{-1}$ threshold above which positive streamflow anomalies were reported by Barnhart et al. (2016) and a $20 \mathrm{~mm}$ day $^{-1}$ classification of very heavy rainfall (Klein Tank et al., 2009) used by Musselman et al. (2017). To examine how daily snowmelt rates respond to simulated warming, we present a quantile analysis of the 25th, 50th, 75th, 90th, 95th, and 99th percentiles of daily snowmelt rates $\geq 1 \mathrm{~mm} \mathrm{day}^{-1}$ from the warmer scenarios compared to those from the nominal case. For this analysis, the model domain was divided into three elevation bands: 1500 to 2250,2250 to 2800 , and $>2800 \mathrm{~m}$ a.s.l., and percentiles of daily snowmelt were computed for all grid cells in each elevation band. The analysis was conducted separately for each of the three water years and seven scenarios. Lastly, we present an analysis of the meteorological conditions that control the response of snowmelt rates to successive degrees of simulated warming.

\section{Results}

Maps of simulated SWE on 1 April, 1 May, and 1 June (Fig. 2) highlight seasonal and interannual SWE patterns and illustrate the great variability of SWE with elevation. The lowest elevations were consistently snow-free during the spring. Middle elevations included a transition zone from snow-free to seasonally persistent snow cover; that transition occurred at progressively higher elevations later in the melt season and occurred earlier (later) in the drier (wet-
Table 2. Average (hourly) air temperature and shortwave radiation values measured at the alpine Topaz Lake meteorological station in the Tokopah Basin for JFM and AMJ of the moderately dry year (2009), near-average year (2008), and moderately wet year (2010).

\begin{tabular}{|c|c|c|c|c|}
\hline & \multicolumn{2}{|c|}{ Air temperature, ${ }^{\circ} \mathrm{C}$} & \multicolumn{2}{|c|}{ Shortwave, $\mathrm{W} \mathrm{m}^{-2}$} \\
\hline & JFM & AMJ & JFM & $\mathrm{AMJ}$ \\
\hline 2009 & -3.2 & 3.3 & 163 & 279 \\
\hline 2008 & -3.6 & 3.4 & 166 & 317 \\
\hline 2010 & -4.0 & 1.3 & 152 & 306 \\
\hline
\end{tabular}

ter) snow years. The upper elevations contained the greatest SWE and most persistent spring snow cover (Fig. 2). The 3-year observation period captured years with belowaverage snowfall (2009; $23 \%$ below-average SWE; hereafter "moderately dry year"), average snowfall (2008; $7 \%$ aboveaverage SWE; hereafter "average year"), and above-average snowfall $(2010 ; 54 \%$ above-average SWE; hereafter "moderately wet year") as determined from regional automated SWE records (Fig. 3 and Table S1 in the Supplement). The average (hourly) air temperature and shortwave radiation values measured at the alpine Topaz Lake station in JanuaryFebruary-March (JFM; the accumulation season) and AprilMay-June (AMJ; the melt season) provide more insight into the meteorological differences amongst the three years. The drier and average years exhibited similar average air temperatures, but the AMJ mean shortwave radiation was lower in the moderately dry year (Table 2) due to higher spring cloudcover (see Fig. 6 in Musselman et al., 2012b). The AMJ period in the moderately wet year was $>2{ }^{\circ} \mathrm{C}$ colder than the other years (Table 2) due to a series of large snowfall events in mid-April (Fig. 3) that prolonged snow cover well into June (see Figs. 2 and 3). By comparison, snow cover measured by the automated SWE stations generally disappeared in May in both the drier and average years (Fig. 3).

\subsection{Model evaluation against observation}

Compared to automated snow pillow SWE measurements, the model performed favorably (RMSE $\leq 100 \mathrm{~mm}$; bias better than $\pm 85 \mathrm{~mm}$ ) at all elevations in 2008 and 2010 (Fig. 3). In 2009, the model underestimated SWE compared to measurements made at the two higher-elevation stations, but accurately simulated SWE at the lower Giant Forest station $(\mathrm{RMSE}=34 \mathrm{~mm}$; bias $=-4 \mathrm{~mm}$; Fig. 3). The greatest model error occurred in 2009 at the Big Meadows station (2317 ma.s.l.) resulting from a significant underestimation of all snow events, possibly due to sensor error, and errors were less at the higher and lower-elevation stations in this year (Fig. 3).

Compared to the range of snow depth measured by six sensors at each of four sites in the forested Wolverton basin, the model accurately captured the seasonal snow depth dynam- 


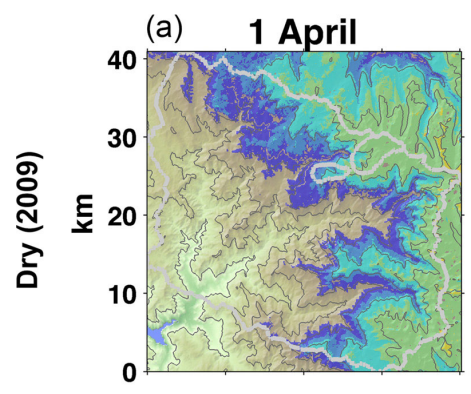

(d)

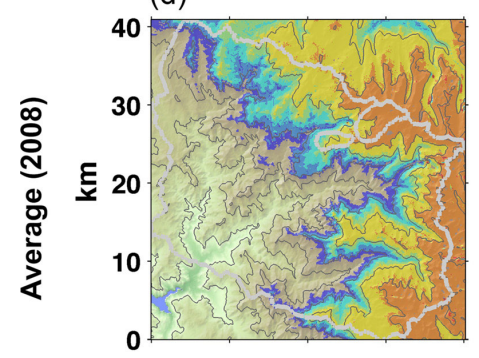

(g)

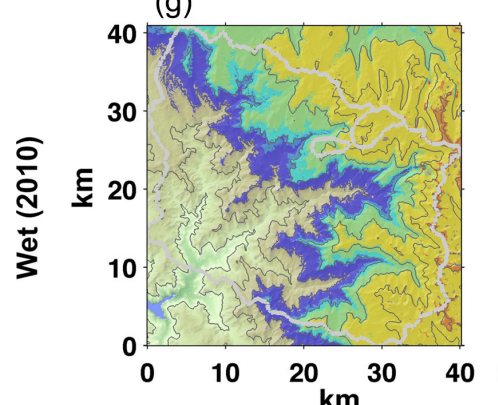

(b) 1 May

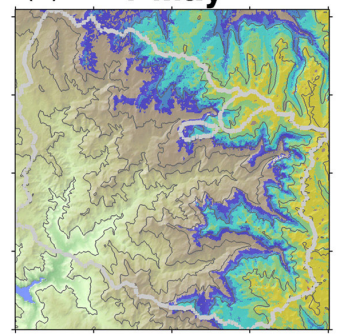

(e)

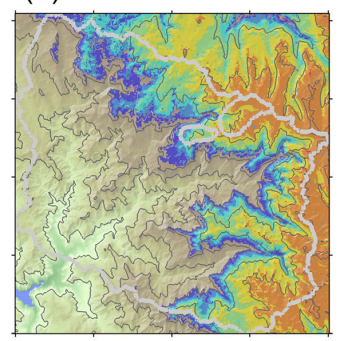

(h)

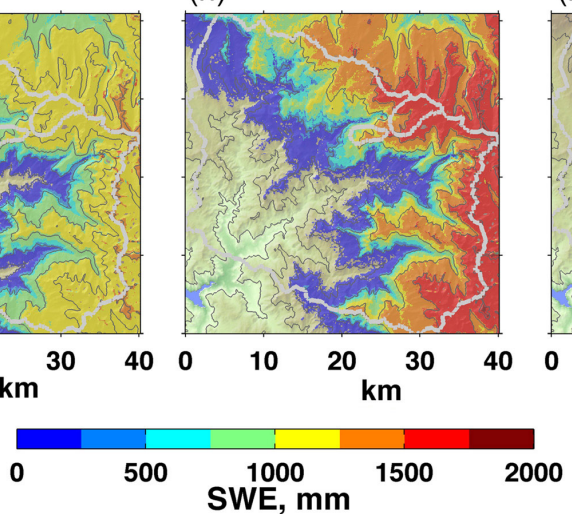

(c) 1 June

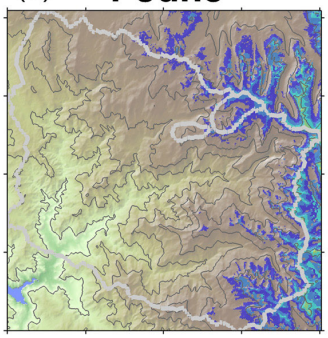

(f)

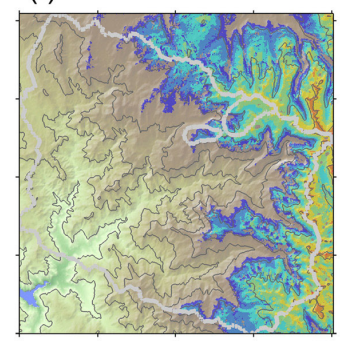

(i)

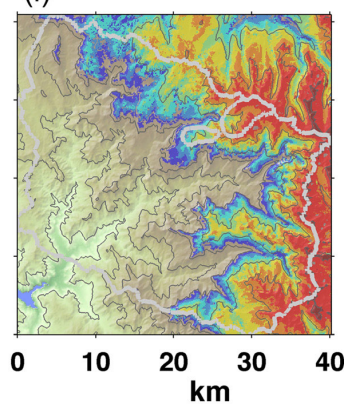

Figure 2. Simulated SWE over the greater Kaweah River basin on the first of April (a, d, h), May (b, e, i), and June (c, f, j) for a moderately dry water year (2009; a, b, c), near-climatological-average water year (2008; d, e, f), and a moderately wet water year (2010; $\mathbf{g}, \mathbf{h}, \mathbf{i})$.

ics, including maximum accumulation, the rate of depletion, and the date of snow disappearance (Fig. 4; note that simulated snow depth is generally within the measurement envelope). The underestimation of SWE in 2009 was not apparent in the verification against the six automated depth measurements at four sites in the Wolverton basin (Fig. 4).

The early April surveys of the alpine Tokopah basin show 2009, 2008, and 2010 being the drier ( $849 \pm 401 \mathrm{~mm} \mathrm{SWE})$, average $(1000 \pm 476 \mathrm{~mm} \mathrm{SWE})$, and wetter $(1265 \pm 310 \mathrm{~mm}$ SWE) snow seasons, respectively (Table S2). Model SWE errors (NMSE) were highest during the melt season when the measured variability was high relative to the mean, and lowest during the accumulation season (Table S2). On average, the forested Wolverton and alpine Tokopah basins exhibited similar NMSE values of $\sim 0.14$ at maximum accumulation. In general, the model tended to overestimate SWE with the exception of the February 2009 Wolverton survey, for which modeled SWE was negatively biased (Table S2). The survey mean bias values were typically much less than the standard deviation of the biases.

In general, model SWE errors were lower when evaluated against the CCSS snow course measurements (Table S3) than the basin-wide survey measurements (Table S2). The large underestimation of SWE in 2009 seen in the comparison against the automated SWE stations (Fig. 3) is also seen in comparison to SWE measured at the two lowest elevation snow course sites (Table S3). Conversely, comparison to the two highest elevation snow course sites indicated a slight positive model bias in 2009. Overall, the model performed best in regions closest to precipitation gauges used to force the model; SWE RMSE values were better explained by this metric than by elevation alone (Fig. S1).

\subsection{Elevation-dependent SWE and snowmelt patterns}

The upper panels of Fig. 5 show the nominal simulations of the daily SWE and melt averaged along elevation bands for 

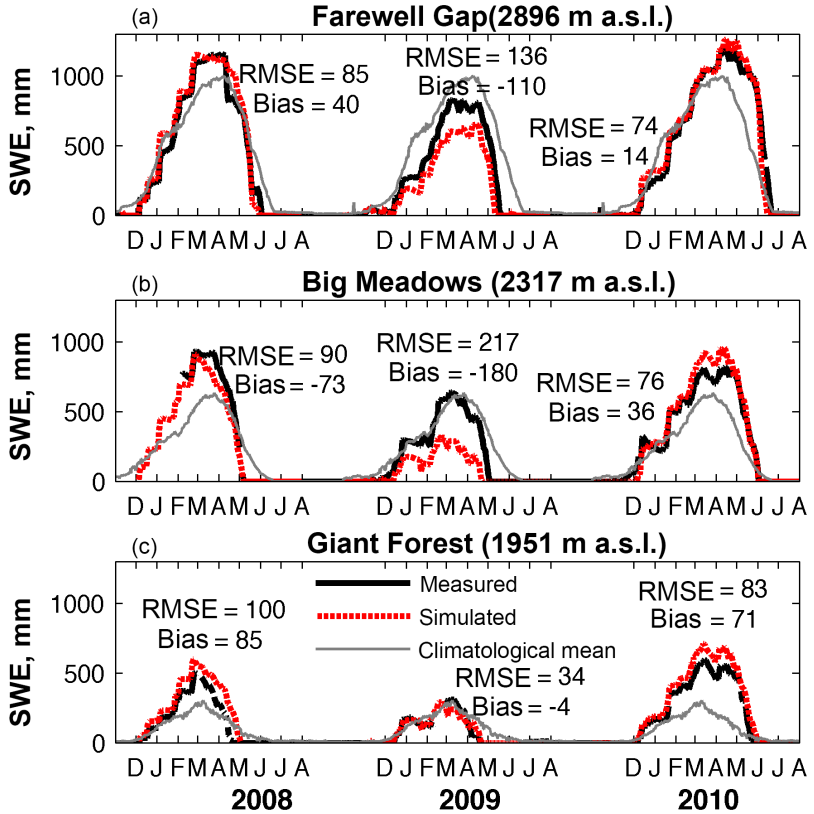

Figure 3. Measured and simulated SWE at the three automated snow stations spanning the middle elevations of the greater Kaweah River basin. The error metrics RMSE and bias, in millimeters, are provided for each station-year. The thin gray line indicates the longterm climatological mean SWE based on 26 years of data (19882014) collected at the Giant Forest and Big Meadows stations and a 15-year record (2000-2014) at the Farewell Gap station.

the three years. Persistent seasonal snowpack was simulated $>1800 \mathrm{~m}$ a.s.l. in all years. Maximum annual SWE increased with elevation (colors in the top row panels of Fig. 5); however, the date of maximum SWE exhibited a complex relationship with elevation, snowfall magnitude and timing, and snowpack persistence that all varied amongst years (Fig. 5). Generally, maximum SWE occurred later with increasing elevation but progressed in a step-wise manner, often with little change over hundreds of vertical meters interspersed with abrupt jumps of 1 to 2 months (Fig. 5; note the occasional large horizontal spacing between " $\mathrm{X}$ " markers of adjacent elevation bands).

Simulated daily melt was episodic in nature with the highest rates ( $>35 \mathrm{~mm} \mathrm{day}^{-1}$; red in the bottom panels of Fig. 5) generally confined to elevations $>2000 \mathrm{~m}$ a.s.l. and the late spring and early summer. The highest elevations and years with more/later snow had the highest melt rates. In all three years, winter melt was generally low $\left(<5 \mathrm{~mm} \mathrm{day}^{-1}\right)$ with rare, episodic, and more intense melt events confined to lower elevations (Fig. 5).

\subsection{Elevation-dependent snowpack and snowmelt response to warming}

In the nominal case, the total meltwater volume summed over each elevation band was consistently greatest between
$2500 \mathrm{~m}$ and $2800 \mathrm{~m}$ a.s.l. (see Fig. 6; right panels), corresponding to the peak in the regional hypsometry (see histograms in Fig. 1). Under the warmer scenarios, the maximum meltwater volume, inferred from the peaks in Fig. 6 , shifts upward in elevation by $\sim 600 \mathrm{~m}$ to the regional tree line (see Fig. 1). This upward elevation shift occurred under $+2,+3$, and $+4{ }^{\circ} \mathrm{C}$ warming for the dry, average, and wet snow seasons, respectively. Additional warming reduced the total melt volume but did not change the elevation at which the maximum volume occurred.

Lower and middle elevations were prone to large reductions in the fraction of historical meltwater volume (see line graphs in Fig. 6). At $2000 \mathrm{~m}$ a.s.l., only $50 \%$ of the historical water in the form of snow remained in $\mathrm{a}+3{ }^{\circ} \mathrm{C}$ scenario, further reducing to $20 \%$ in the $+5{ }^{\circ} \mathrm{C}$ scenario. Overall, snow at the upper elevations in the moderately dry snow season was more susceptible to large reductions (Fig. 6). Conversely, upper elevation snowpack during the average and higher snowfall seasons was more resilient to warming. For example, at $2700 \mathrm{~m}$ a.s.l., $+1{ }^{\circ} \mathrm{C}$ warming reduced annual meltwater volume by 1,3 , and $11 \%$ in the wetter, average, and drier snow seasons, respectively; those values increased to 7,21 , and $28 \%$ in the $+3{ }^{\circ} \mathrm{C}$ scenario.

Despite elevation-dependent nonlinear meltwater response to warming, the domain-total meltwater volume exhibited linear response to successive warming. Figure 7 shows linear regressions fit to the fraction of the nominal-case total meltwater for each scenario and year (see Table S4). The dry and average years were slightly more susceptible to warming $\left(-10.5\right.$ to $-10.8 \%$ change $\left.\operatorname{per}^{\circ} \mathrm{C}\right)$ than the wetter year $\left(-9.3 \%\right.$ change per $\left.{ }^{\circ} \mathrm{C}\right)$. Sublimation estimates ranged from 5 to $9 \%$ in the nominal case to 8 to $14 \%$ in the $+6^{\circ} \mathrm{C}$ scenario (Table S4).

Warmer temperatures impact not only the total annual meltwater, but also the rate at which meltwater is produced. Figure 8 shows the fraction of the total meltwater per unit area over the elevation profile that is produced at high $\left(\geq 15 \mathrm{~mm} \mathrm{day}^{-1}\right.$ ) melt rates; the complement of that fraction occurs at lower $\left(<15 \mathrm{~mm} \mathrm{day}^{-1}\right)$ rates. Consistently, meltwater production at upper elevations is dominated by high melt rates, while at lower-elevations melt rates are predominately low. At $\sim 2200 \mathrm{~m}$ a.s.l., melt in the nominal cases occurred equally at low and high rates; above this middle elevation zone, melt occurs at high rates $\left(\geq 15 \mathrm{~mm} \mathrm{day}^{-1}\right)$ and at low rates $\left(<15 \mathrm{~mm} \mathrm{day}^{-1}\right)$ below this elevation (see black circle markers in Fig. 8). Warming greatly decreases the fraction of meltwater produced at high melt rates and increases that produced at low rates (see lower colored graphs in Fig. 8). As a result, the elevation at which meltwater is produced equally at low and high rates is pushed upward by $\sim 150 \mathrm{~m}^{\circ} \mathrm{C}^{-1}$ (Fig. 8). The greatest melt rate reductions occur at forested elevations with generally lesser change in alpine areas above $\sim 3300$ m a.s.l.

There is a general tendency toward lower snowmelt rates in response to successive warming with the lower elevations 

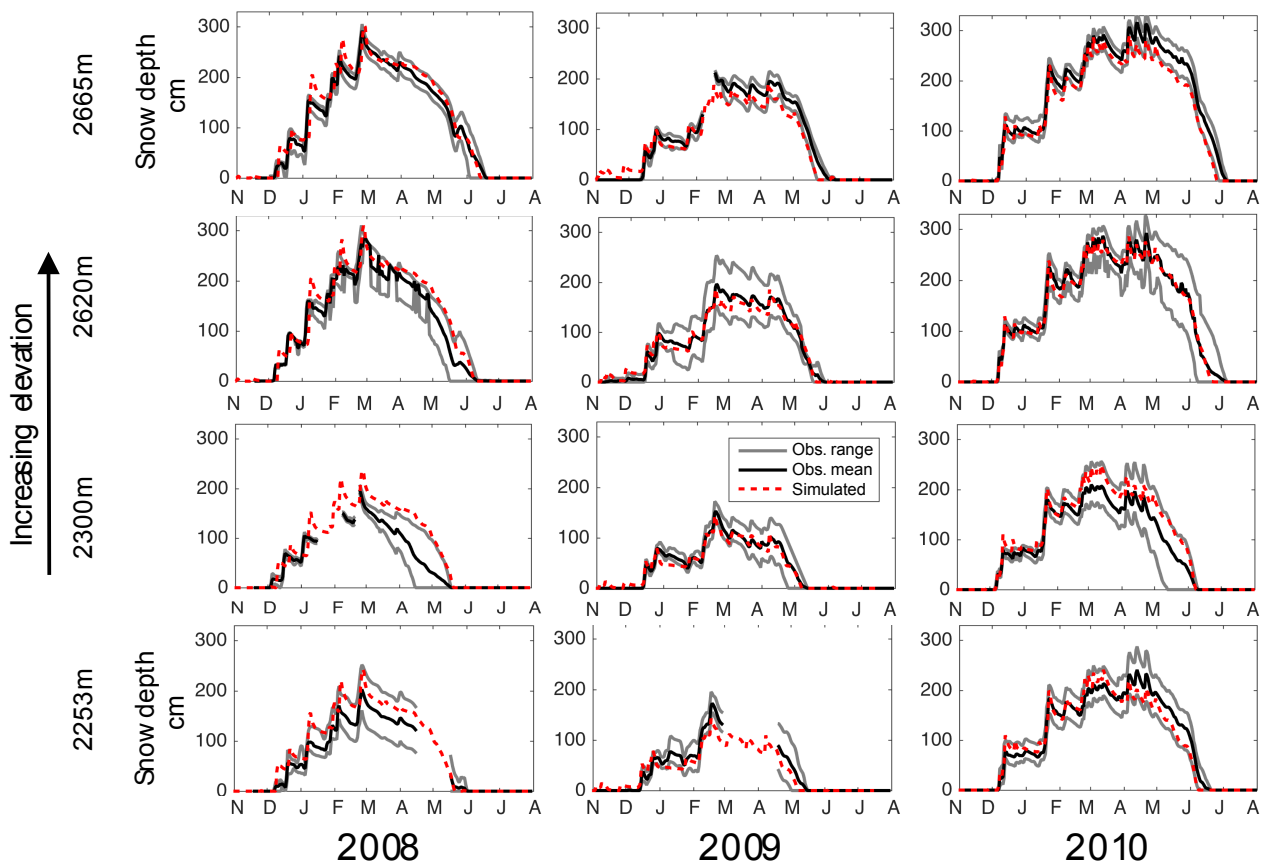

2009

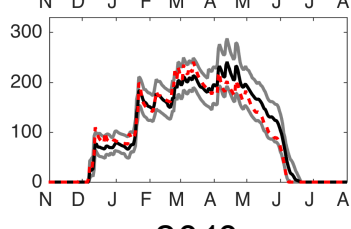

Figure 4. Comparison of three years (panel columns) of daily ( $x$ axes) simulated (red lines) snow depth and the six-sensor observed range (gray lines) and mean (bold lines) snow depth measured by automated sensors at four research sites (panel rows) at different elevations in the Wolverton basin.
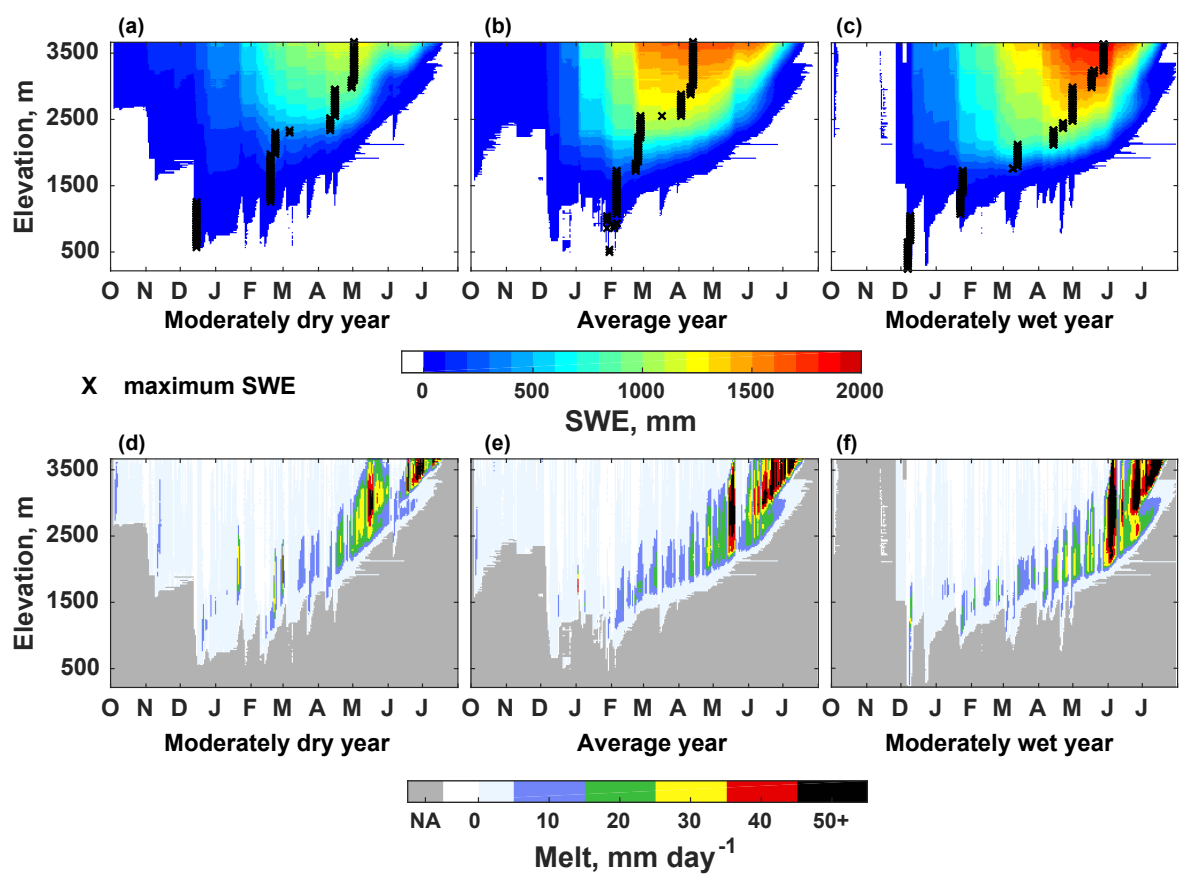

Figure 5. Distribution of (a, b, c) SWE and (bottom panels) daily melt by elevation (mean values within $18 \mathrm{~m}$ elevation bins; $y$ axes) and time (daily; $x$ axes) for a moderately dry $(2009 ; \mathbf{a}, \mathbf{d})$, near-average $(2008 ; \mathbf{b}, \mathbf{e})$, and moderately wet $(2010$; c, f) snow season. The grey color in the lower panels indicates times when there is no snow to melt (NA). The elevation-specific dates of maximum SWE are indicated. 


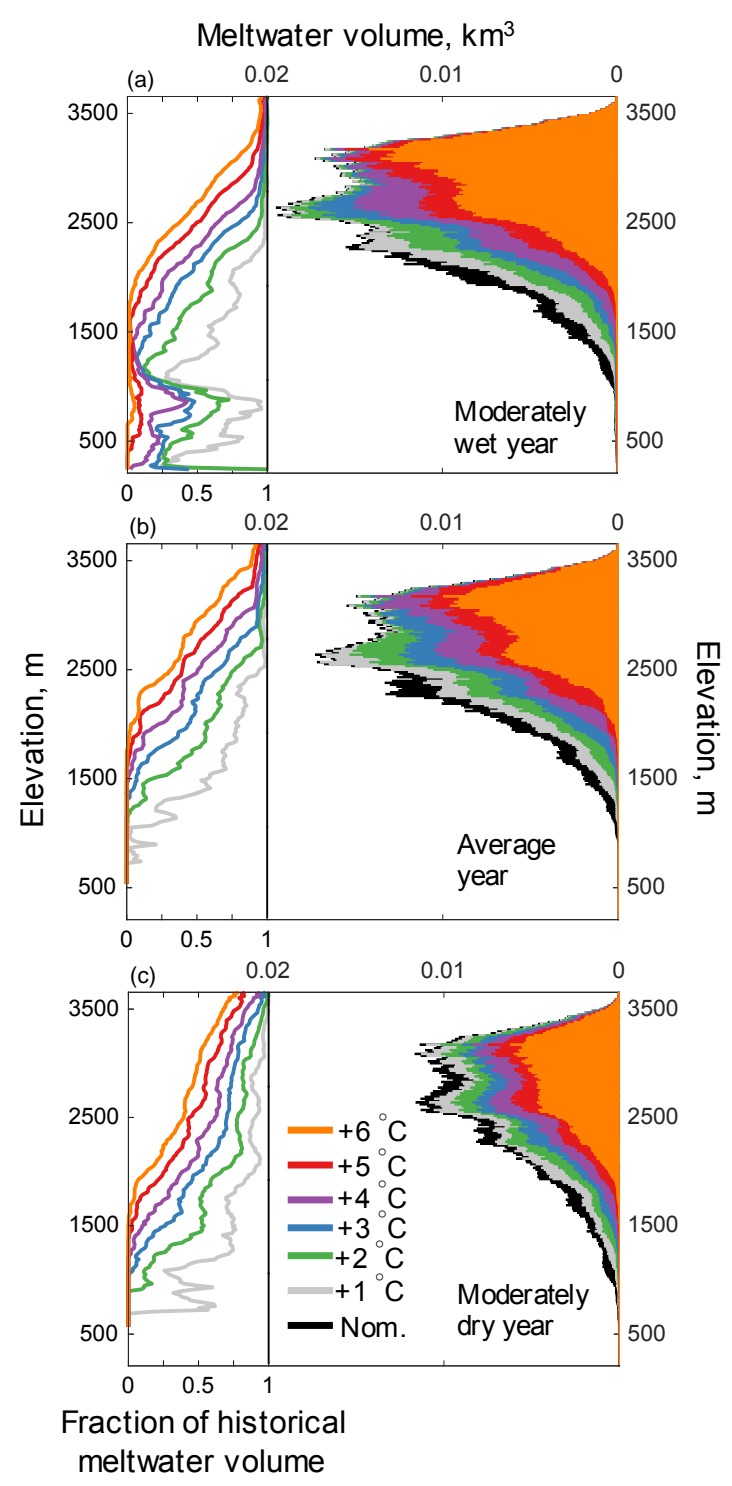

Figure 6. The elevation distribution ( $y$ axes) of simulated annual meltwater volume (right bar graphs) and the fraction of that historical meltwater (line graphs) for each warmer scenario (colors; see legend) for the (a) moderately wet, (b) average, and (c) moderately dry snow seasons. The total meltwater was summed within the same elevation bins used in Fig. 5.

and the year with the most snowfall (and latest storm events) prone to the greatest reductions (Fig. 9). There are notable exceptions. For a majority of the simulations, extreme melt rates (99th percentiles; downward-facing triangles in Fig. 9) actually increase (inferred from markers plotting above the $1: 1$ line) at elevations $>2800 \mathrm{~m}$ a.s.l. in all years (top panels) and in the drier year at elevations $>2250 \mathrm{~m}$ a.s.l. To better understand why these extreme melt rates differ in trend from the lower percentiles, we provide a brief analysis of $2009 \mathrm{ex}-$ treme melt events. The analysis is limited to elevations above

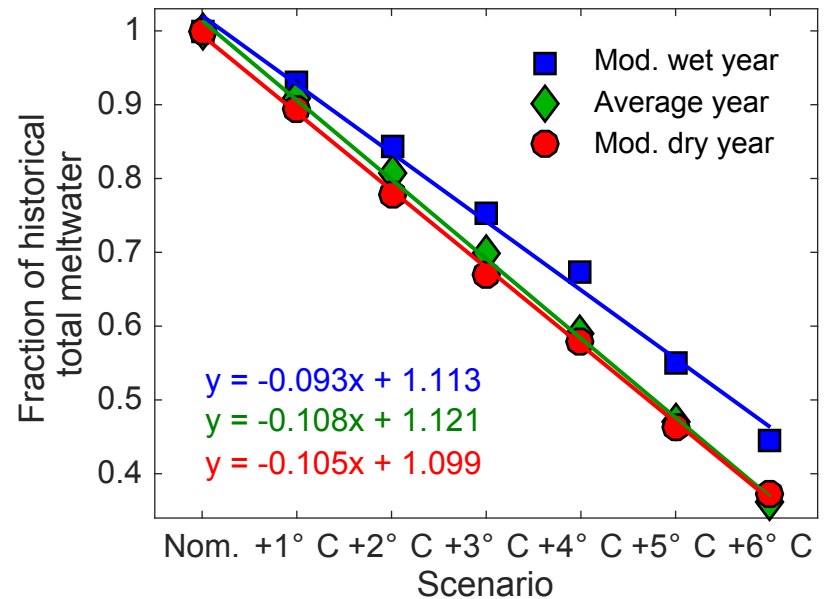

Figure 7. The fraction of simulated domain-wide historical meltwater ( $y$ axis), relative to the nominal case, for each warmer temperature scenario ( $x$ axis) for the three years (marker type and color). The colored lines and associated regression equations show linear fits to the data. For each year, the $R^{2}$ value was $>0.99$ and the $p$ value was $\ll 1 \times 10^{-6}$.

$2250 \mathrm{~m}$ a.s.l. where a threshold of $40 \mathrm{~mm} \mathrm{day}^{-1}$ designates extreme (99th percentiles) melt rates (see Fig. 9).

In the spring, extreme melt affected a very limited portion of the domain on any given day (inferred from blue colors on the right in the top panel of Fig. 10), and the spatial extent of extreme melt generally decreased in response to warming. Conversely, three distinct extreme melt events on 21 January, 22 February, and 1 March 2009 (arrows in Fig. 10) exhibit large increases in the fraction of the domain affected, with the January and March events increasing in spatial extent until $+4{ }^{\circ} \mathrm{C}$ before decreasing with additional warming. The simulated melt events were not associated with substantial rainfall, but rather cloudy and/or windy conditions with high longwave radiation that generally occurred under warmer-than-average temperatures in the nominal case. Measured meteorological conditions for these days are provided in Table 3. These warm and cloudy winter conditions were insufficient to produce widespread extreme melt in the nominal case; melt was limited to elevations $<2000 \mathrm{~m}$ a.s.l. and generally did not exceed the 99th percentile (Table 3). Additional warming caused extreme rates of melt to occur at increasingly higher elevations at a time of substantial snow cover (Fig. 10).

\section{Discussion}

\subsection{Snowmelt response to simulated warming}

Our results confirm that climate warming will have uneven effects on the California landscape (Cayan et al., 2008) and that elevation is a critical determinant of snowpack-climate 

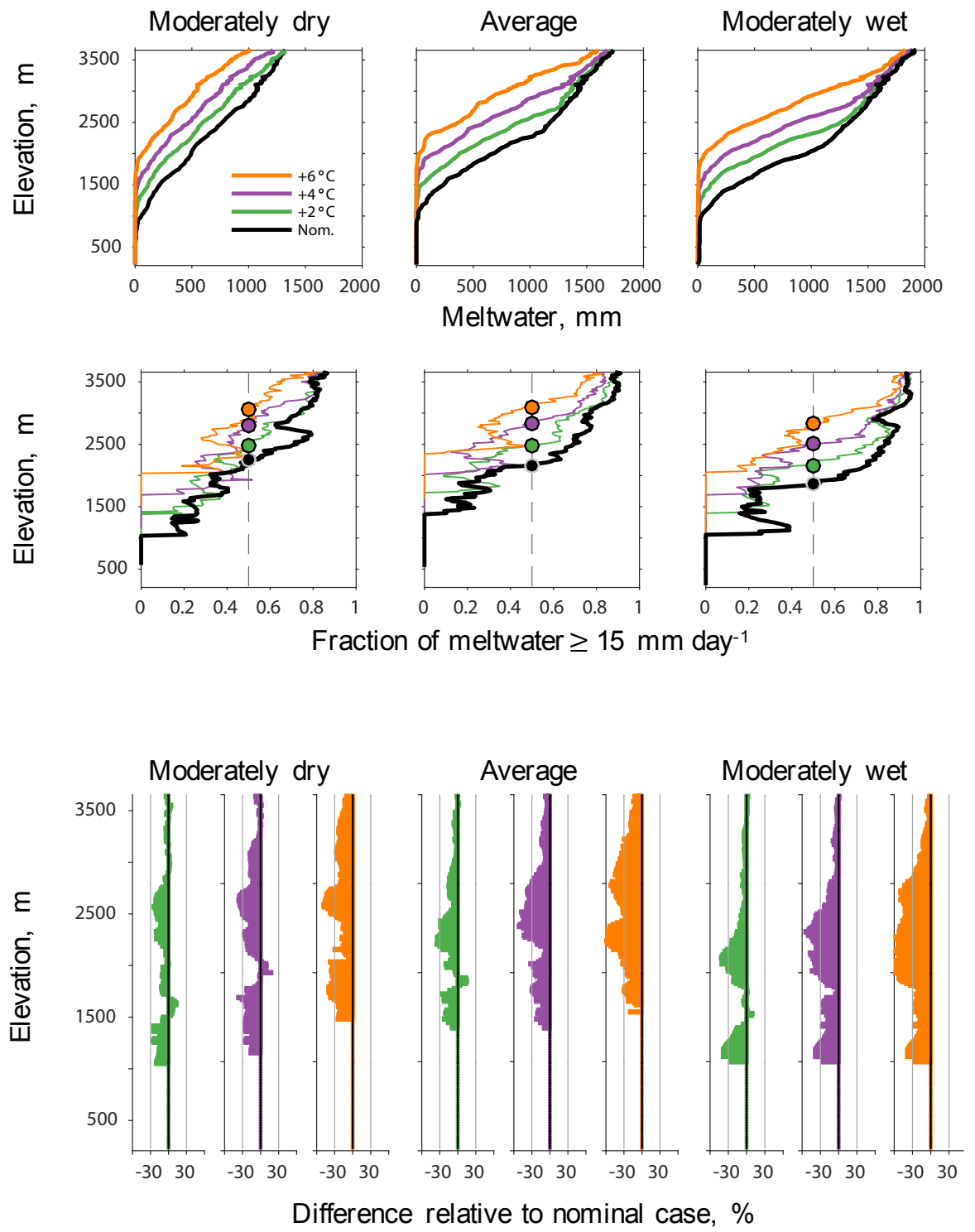

Figure 8. Top row of panels: the elevation distribution ( $y$ axes) of the average total depth of annual meltwater ( $x$ axes) simulated for the nominal case (black lines) and select perturbed temperature scenarios (colored lines). Second row of panels: the fraction of annual meltwater produced at snowmelt rates $\geq 15 \mathrm{~mm}^{-1}$ day $^{-1}$. The colored circles indicate elevations at which simulated melt occurs equally at rates $\geq 15 \mathrm{~mm} \mathrm{day}^{-1}$ and $<15 \mathrm{~mm} \mathrm{day}^{-1}$. The lower panels of colored graphs show the differences from the nominal case, reported in percent of annual meltwater, produced at snowmelt rates $\geq 15 \mathrm{~mm}_{\text {day }}{ }^{-1}$ for the three select scenarios. Results are shown for the moderately dry (2009; left column of plots), near-average (2008; middle column of plots), and moderately wet (2010; right column of plots) snow seasons.

sensitivity. Despite the simplicity of our climate sensitivity method, the predicted sensitivity of total snow volume to warming of -9.3 to $-10.8 \%{ }^{\circ} \mathrm{C}^{-1}$ is consistent with previous studies using either statistical and dynamical downscaling of GCM output (Sun et al., $2016 ;-9.3 \%{ }^{\circ} \mathrm{C}^{-1}$ ) or a simple statistical snow model trained on observations (Howat and Tulaczyk, $2005 ;-10 \%{ }^{\circ} \mathrm{C}^{-1}$ ). The consistency suggests that these models of varying complexity adequately treat the warming-induced shift from snowfall to rain. This confirms recent findings by Schlögl et al. (2016) that snow model er- rors may be less important when relative climate sensitivity metrics are evaluated. Further, we show linearity in the sensitivity of domain-wide annual meltwater volume to successive degrees of warming. The year with the most snowfall, characterized by late snowfall events and cold spring (AMJ) air temperatures, was slightly more resilient $\left(-9.3 \%{ }^{\circ} \mathrm{C}^{-1}\right)$ to warming than the drier or average snow years. In a study of the sensitivity of snow to warming in Mediterranean climates, including the Tokopah basin, López-Moreno et al. (2017) report that simulated changes in precipitation mag- 
Moderately dry year (2009)

(a)
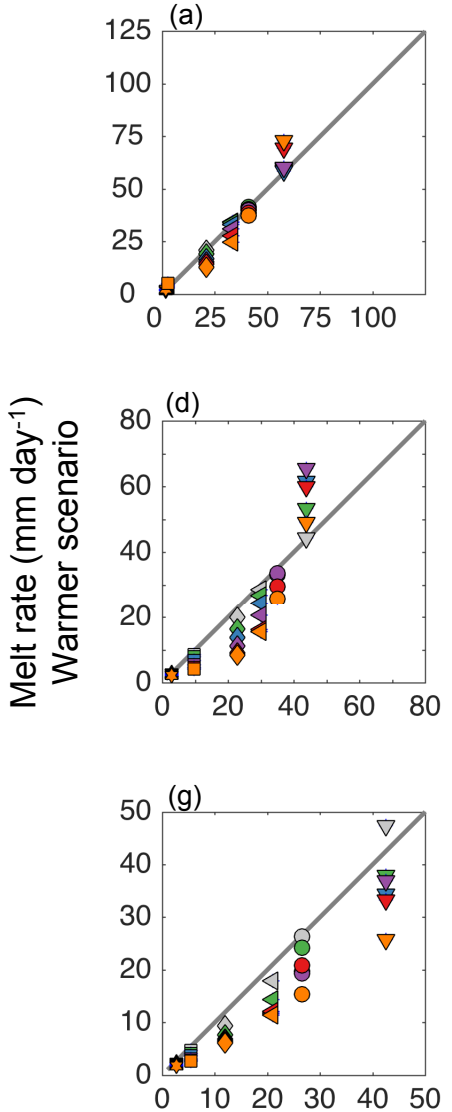

Average year (2008)

$>2800 \mathrm{~m}$

(b)

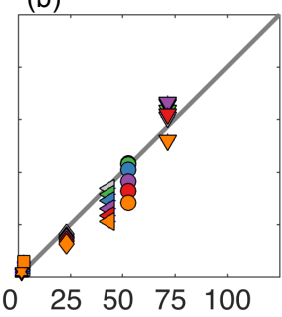

$2250 m-2800 m$

\section{(e)}

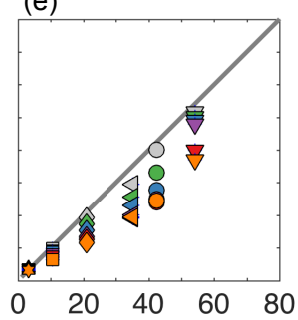

$1500 m-2250 m$ (h)

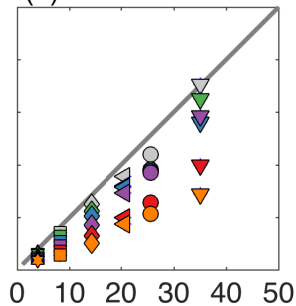

Melt rate $\left(\mathrm{mm}\right.$ day $\left.^{-1}\right)$

Nominal case
Moderately wet year (2010)
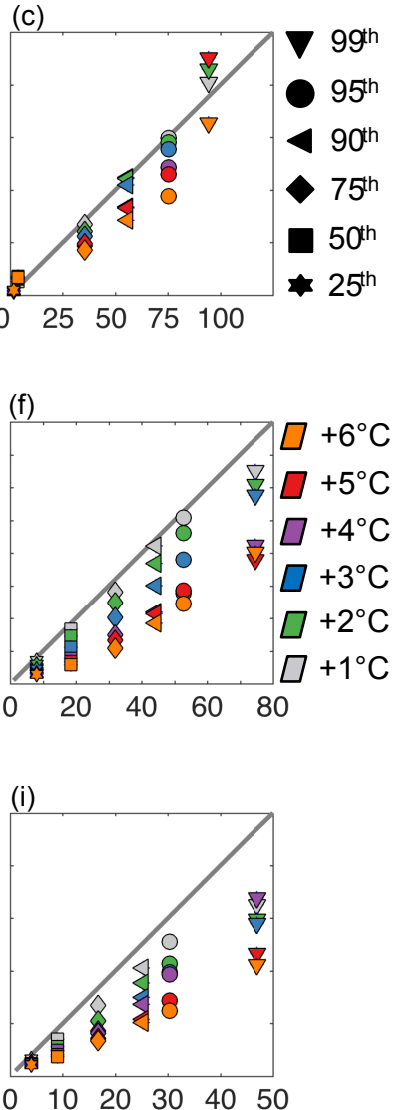

$0 \quad 102030 \quad 4050$

Figure 9. Quantile plots of simulated melt rates for the nominal ( $x$ axes) and warmer scenarios ( $y$ axes) for model grid cells characterized as high elevation (> 2800 m; a, b, c), middle elevation (2250-2800 m; d, e, f), and lower elevation (1500-2250 m) regions for the moderately dry year $(\mathbf{a}, \mathbf{d}, \mathbf{g})$, average year $(\mathbf{b}, \mathbf{e}, \mathbf{h})$, and moderately wet year $(\mathbf{c}, \mathbf{f}, \mathbf{i})$. Marker colors correspond to the six different temperature perturbations. Plotted in each graph are the 25th, 50th, 75th, 90th, 95th, and 99th percentiles (marker shapes) of daily snowmelt rates $\geq 1 \mathrm{~mm}^{\mathrm{tay}}{ }^{-1}$ for all grid cells within each water year and elevation range. The $1: 1$ lines are plotted for reference.

nitude $( \pm 20 \%)$ did not affect the relative snowpack climate sensitivity to warming. Thus, snowmelt rates may be more sensitive to changes in the seasonal timing of precipitation than to changes in precipitation magnitude. This supports the conclusions of Cooper et al. (2016) that record low snowpack years may not serve as appropriate analogues for the climate sensitivity of snow.

In a warmer climate, shifts from snowfall to rain are likely to combine with shifts in snowmelt timing to cause earlier water availability relative to the historical period. As a result, the ephemeral snow zone is expected to progress upward in elevation (Minder, 2010) and shift the areal distribution of SWE toward higher, unmonitored elevations. Indeed, the $+3{ }^{\circ} \mathrm{C}$ scenario shifted the elevation of maximum annual meltwater volume above that of the highest regional SWE observing station. The results confirm previous findings in the US Pacific Northwest that the current observing network design may be insufficient in a warmer world (Gleason et al., 2017; Sproles et al., 2017). Warmer temperatures and earlier melt timing (Stewart et al., 2004) also influence the rate of meltwater production (Musselman et al., 2017), a critical determinant of streamflow (Barnhart et al., 2016), forest carbon uptake (Winchell et al., 2016), and flood hazard (Hamlet and Lettenmaier, 2007). Despite a strong negative relationship between temperature and elevation, we show a positive relationship between elevation and seasonal snowmelt rates. Compared to earlier melt at lower elevations, later snowmelt at upper elevations was more rapid due largely to higher solar insolation coincident with later melt (Musselman et al., 2012b). Prolonged snow cover at upper, compared to lower 


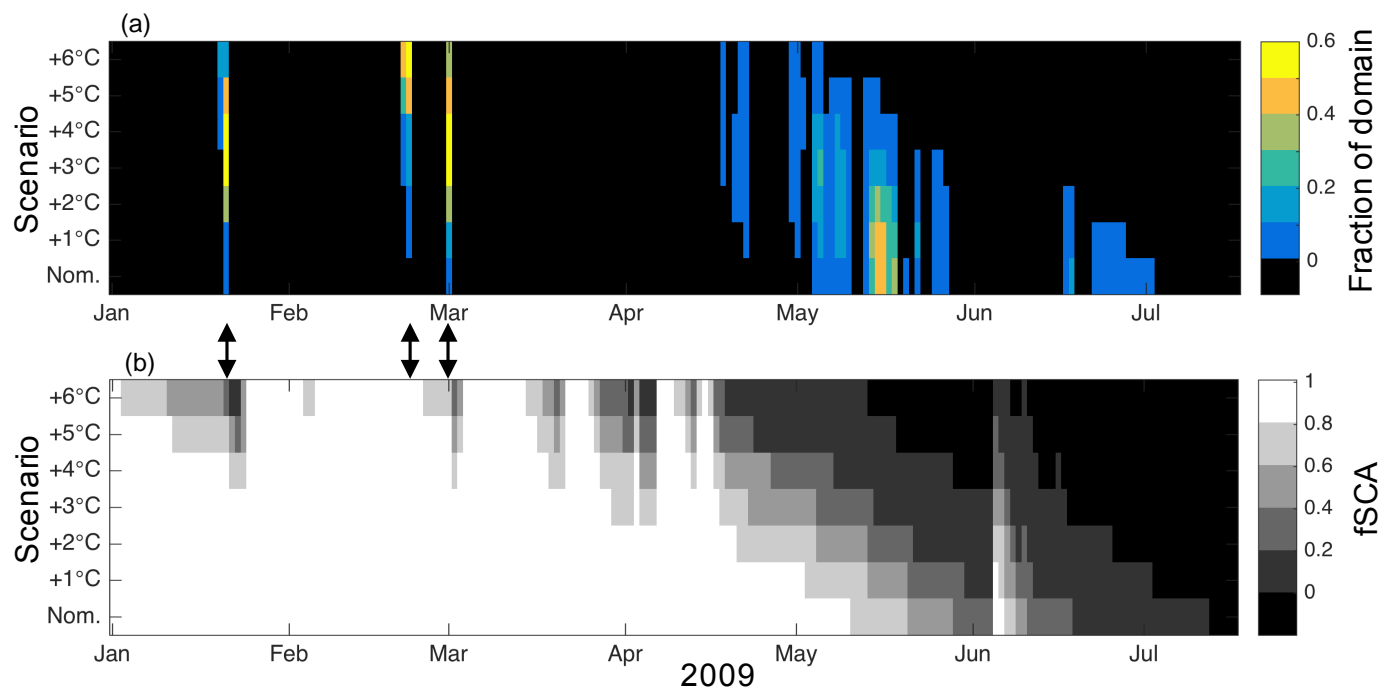

Figure 10. Daily extreme snowmelt in 2009 (melt rates $>40 \mathrm{~mm} \mathrm{day}^{-1}$ at model grid cells $>2250 \mathrm{~m}$ a.s.l., corresponding to extreme melt rates, $\geq 99$ th percentile; see Fig. 8) as simulated by the nominal (Nom.) and six perturbed temperature scenarios ( $y$ axes) shown as the (a) fraction of the area undergoing extreme melt. The lower panel shows the fraction of snow-covered area (fSCA) for the same time period and domain. Arrows indicate (winter) melt events (see Table 3 for meteorological conditions and averages).

Table 3. Mean daily values of hourly measured meteorological variables (nominal mean) during the three mid-winter melt events in 2009 (see Fig. 10) compared to the average conditions measured at eight stations $>2250 \mathrm{~m}$ a.s.l. computed on 11 days centered on the event dates, averaged over the three years of the study. Precipitation is reported as the daily sum of measured values. Melt rates simulated in the nominal case are reported as the mean value computed over all grid elements $>2250 \mathrm{~m}$ a.s.l. and the maximum value over the full domain with the corresponding elevation.

\begin{tabular}{|c|c|c|c|}
\hline Met. variable & $21 \mathrm{Jan}$ & $22 \mathrm{Feb}$ & $1 \mathrm{Mar}$ \\
\hline Air temp., ${ }^{\circ} \mathrm{C}$ & $2.8 /-0.5$ & $-0.7 / 0.6$ & $4.4 / 1.0$ \\
\hline Shortwave, $\mathrm{W} \mathrm{m}^{-2}$ & $57 / 96$ & $83 / 152$ & $163 / 176$ \\
\hline Longwave, $\mathrm{W} \mathrm{m}^{-2}$ & $292 / 232$ & $297 / 226$ & $266 / 217$ \\
\hline Wind, $\mathrm{m} \mathrm{s}^{-1}$ & $4.0 / 4.3$ & $4.6 / 4.0$ & $7.2 / 4.4$ \\
\hline Precipitation, mm & 0.0 & 4.3 & 0.0 \\
\hline $\begin{array}{l}\text { Mean melt rate, } \mathrm{mm} \mathrm{d}^{-1} \\
\text { nom. sim. }(>2250 \mathrm{~m})\end{array}$ & 6.5 & 1.5 & 4.7 \\
\hline $\begin{array}{l}\text { Max. melt rate, } \mathrm{mm} \mathrm{d}^{-1} \\
\text { nom. sim. (elev., } \mathrm{m})\end{array}$ & $30.6(1897)$ & $28.3(1586)$ & $44.0(1741)$ \\
\hline
\end{tabular}

elevations, and in wetter, compared to drier snow seasons, is an important factor in interpreting snowmelt temperature sensitivity results.

We show a general tendency toward lower melt rates in response to warming. In contrast to Musselman et al. (2017), which evaluated mean snowmelt response to a single greenhouse gas emissions scenario at $4 \mathrm{~km}$ resolution, we evaluate a range of potential warming, examine the percentile distribution of snowmelt response, and elucidate the process along elevational gradients most relevant to basin-wide runoff. This is a critical advancement in understanding how and where meltwater production is impacted by warming, an evaluation that cannot be achieved with the type of "high-resolution" climate modeling used in Musselman et al. (2017). Importantly, we report an emergence (i.e., not present in the historical simulations) and spatial expansion of extreme winter melt events and, conversely, a decline in extreme melt during spring. Increases in extreme winter melt occurred under warm and cloudy conditions, and decreases in extreme spring melt were due to reduced snow-cover persistence. This is an important new finding with implications on flood hazard and reservoir management. The general tendency toward slower snowmelt rates and higher extreme values is analogous to the expected climate change impacts on precipitation, where high-intensity events are expected to increase despite projected declines in total (e.g., summer) precipitation (Prein et al., 2017; Trenberth, 2011).

\subsection{Hydrologic implications}

Increases in extreme winter melt rates, combined with a greater proportion of precipitation falling as rain could locally increase winter flood risk. Higher winter runoff complicates reservoir management faced with competing objectives to maintain flood control storage capacity during winter and to maximize water storage during spring in preparation for the arid summer. In this context, substantial winter runoff may have to be released downstream thereby reducing summer water storage required for agriculture, fish and wildlife management, hydropower production, recreation, water quality, and municipal supply (Barnett and Pierce, 2009; Lettenmaier et al., 1999). We show that historical extreme melt rates (99th percentiles) impact a relatively lim- 
ited area (generally $<30 \%$ of land area above $2250 \mathrm{~m}$ a.s.l.) at any given time. This is likely due to snowpack cold content and/or cool air temperatures limiting melt at upper elevations and low snow-cover fraction limiting melt at lower elevations. Compared to the historical period, warming doubles the basin area that experiences extreme melt, and shifts its occurrence from spring to winter. The increased spatial extent, intensity, and frequency of extreme winter snowmelt events may have significant implications for antecedent moisture conditions and associated flood risk.

Snowmelt rates have been mechanistically linked to streamflow production (Barnhart et al., 2016), but less understood are the potential implications of climate-induced changes in snowmelt rates on subsurface water storage, evapotranspiration, and streamflow response. For example, recent empirical evidence that a precipitation shift from snow towards rain will lead to a decrease in streamflow (Berghuijs et al., 2014) lacks definitive causation. Compared to soil, snow cover exhibits different water routing mechanisms. For example, lateral downslope flow of water along snowpack layers has been shown to explain the observed rapid delivery of water to streams and anomalously high contributions of event water to the hydrograph during rain on snow and snowmelt (Eiriksson et al., 2013). One hypothesis is that as snow cover becomes less persistent in a warmer world, and snowmelt rates decline, this rapid slope-scale redistribution of water toward stream channels will slow or cease, increasing the soil residence time of water. Longer soil residence time can increase the partitioning of water to evapotranspiration, and thus decrease streamflow. While not available in this region, snowmelt lysimeters may be useful additions to long-term research sites to better characterize variability and trends in the flux of water to the soil system.

Other empirical and modeling studies have reported declines in summertime streamflow due to earlier snowmelt runoff and earlier depletion of shallow aquifers (Huntington and Niswonger, 2012; Luce and Holden, 2009). Catchment wetness (i.e., soil moisture content and shallow groundwater levels) has substantial impact on runoff response in mountainous areas with distinct thresholds determining relationships amongst wetness, streamflow, and contributing area (Penna et al., 2011), with behavior controlled by soil type, subsurface storage capacity, and climate. These factors are also important drivers of evapotranspiration (Christensen et al., 2008; Lundquist and Loheide, 2011) and the regional variability of hydrologic sensitivity to climate change (Tague et al., 2008). In this regard, percentage reductions in future streamflow may be more substantial than the meltwater reductions reported here because slower snowmelt is less efficient at generating streamflow.

\subsection{Sources of uncertainty and caveats}

Improved model error characterization for the baseline (nominal) years is a critical step toward informed interpretation of the results of our climate change sensitivity analysis. While snow model errors may be less important when relative climate sensitivity metrics are evaluated (Schlögl et al., 2016), runoff simulations require accurate representation of snowpack volume and melt rates. Simulated snow depth values were within the range of observations from automated sensors at four sites spanning elevation, forest density, slope and aspect. This verification provides confidence in the model to capture accumulation, melt rates, and the date of snow disappearance across spatial and temporal scales.

Notwithstanding the abovementioned, there are inherent strengths and weaknesses of the different validation data sets. For example, automated SWE stations were often colocated with meteorological stations used to force the model; thus, the full potential for model error may not be evaluated at these locations. A fairer model assessment is possible when using data from the plot- and basin-scale snow surveys, which can be farther away from the local meteorological stations. In another example, the plot-scale survey design samples many SWE measurements within a $100 \mathrm{~m}$ grid cell, while the basin-scale surveys sampled snow depth at only three measurement points, relying on extrapolation from a few density measurements to estimate SWE. The automated SWE stations only sample a single point. The degree to which these point samples represent the average value over an area consistent with the model grid scale is a source of inherent discrepancy between models and observations, independent of model skill (Trujillo and Lehning, 2015). Overall, the model performed best in regions closest to precipitation gauges used to force the model (Fig. S1) and tended to slightly overestimate SWE at upper elevations (Table S3) where no precipitation measurements are available. The results complement our finding that the current precipitation and snowpack observation network may be insufficient in a warmer world where the majority of snow water resources shift to higher, unmonitored elevations where snow model error is greatest.

Our assumption of a uniform temperature perturbation does not consider changes in climate dynamics at diurnal (e.g., nighttime vs. daytime temperature changes), synoptic (e.g., number of cool vs. warm days), or seasonal (e.g., winter vs. spring temperature changes) scales. Furthermore, by not perturbing the measured atmospheric emissivity used in the warmer scenarios, we may underestimate the longwave contribution to snowmelt. Atmospheric emissivity varies as a function of column-integrated temperature, specific humidity, and cloud structure above a site (Flerchinger et al., 2009). All of these interactions may be best characterized using GCM output dynamically downscaled to fine resolutions with regional climate models (e.g., Liu et al., 2017; Sun et al., 2016) or within a delta-change approach that considers the range of uncertainties in the climate change signal of different emissions scenarios (e.g., Marty et al., 2017). By not addressing the snow-albedo feedback between snowcover depletion and warmer temperatures (Letcher and Min- 
der, 2015; Pepin and Lundquist, 2008), it is possible that we underestimate regional air temperature changes toward the end of the melt season in the warmer scenarios. Such negative temperature biases would cause underestimation of the snow depletion rate and, ultimately, the snowpack sensitivity to warming. However, these biases may be partially mitigated by our assumption that the winter and spring, and nighttime and daytime, air temperatures warm uniformly.

Sublimation estimates of 5 to $9 \%$ in the nominal case to 8 to $14 \%$ in the $+6{ }^{\circ} \mathrm{C}$ scenario (Table S4) are on the lowerto-middle end of the reported regional values of 2 to $3 \%$ (West and Knoerr, 1959) to 20\% (Marks and Dozier, 1992). The large range highlights challenges and disparities in measuring (e.g., Molotch et al., 2007; Sexstone et al., 2016) and modeling (Etchevers et al., 2004) turbulent exchange, which are further compounded in mountainous terrain due to the challenges of wind-flow simulation (Musselman et al., 2015). The simulated reductions in snowmelt volume due to increased sublimation are very small compared to reductions caused by the warming induced shift from snow to rain. However, by not considering blowing snow and subsequent sublimation losses (i.e., overestimating alpine snowpack), we may further underestimate snowpack sensitivity to warming.

In light of the potential errors discussed above, our results should be considered somewhat conservative. Longer-term snow and runoff simulations at scales sufficient to resolve mountain climate elevation gradients are needed both as reanalysis to understand historical conditions (e.g., snow reanalysis by Margulis et al., 2016) and forced by large suites of future climate scenarios (e.g., Eyring et al., 2016) that dynamically resolve different model realizations of climate response to different greenhouse gas emissions scenarios. Such efforts will best inform, and constrain the uncertainty of, potential impacts of climate change on flood risk and water availability. Toward this goal, our work makes inroads to quantify how snowpack and melt dynamics respond to incremental warming over an elevation profile characteristic of a foothills-to-headwaters mountain front. The results offer insight into the sensitivity of snow water resources to climate change in the Sierra Nevada, California, with implications for other regions as well.

\section{Conclusions}

We present a climate sensitivity experiment to investigate how historical snow water resources and melt rates respond to successively warmer temperatures over a large elevation gradient in the southern Sierra Nevada, California. Good agreement between simulations and an unprecedented array of ground-based observations of SWE (RMSE $\leq 100 \mathrm{~mm}$; bias better than $\pm 85 \mathrm{~mm}$ ) and snow depth (within multisensor range) is shown. Three primary findings emerge from the simulations. First, the sensitivity of total snow-water volume to warming is -9.3 to $-10.8 \%$ per ${ }^{\circ} \mathrm{C}$. The snow sea- son characterized by above-average snowfall and cold spring storm events was most resilient to warming; however, it also exhibited the greatest shift toward slower melt. Thus, snowmelt rates may be more sensitive to changes in the seasonal timing of precipitation than to changes in precipitation magnitude. Second, the middle elevations, which are dominated by forest cover and comprise a disproportionately large basin area, exhibit the greatest snowpack reductions and the largest shift toward slower snowmelt. Hence, warmingrelated impacts on runoff production and ecosystem function may be particularly acute in these areas. Third, increases in the frequency, intensity, and spatial extent of extreme winter melt events occur with successive warming. Warminginduced extreme (winter) melt impacts an area nearly twice as large as that simulated at any time in the historical period. The changes in extreme snowmelt events have implications for antecedent moisture conditions and associated flood risk. When considered together, the elevation-dependent climate sensitivity of snowmelt revealed herein has broad implications for water supply monitoring, streamflow production, flood control, and ecosystem function in a warmer world.

Data availability. All data and model output presented herein are available upon request from the corresponding author.

\section{The Supplement related to this article is available online at https://doi.org/10.5194/tc-11-2847-2017-supplement.}

Competing interests. The authors declare that they have no conflict of interest.

Acknowledgements. The authors thank Sequoia National Park for support of research efforts. Financial support was provided by the National Science Foundation grants EAR-1032295, EAR1032308, and EAR-1246473, the Southern Sierra Critical Zone Observatory (EAR-0725097), a Major Research Instrumentation grant (EAR-0619947), and the Mountain Research Initiative. The first author was supported by a National Aeronautics and Space Administration (NASA) Earth System Science Fellowship. Roger Bales Bales and Peter Kirchner supported hydrometeorological infrastructure in the Wolverton basin. James Sickman and John Melack provided solar radiation and snow survey data from the Tokopah basin. Alpine3D is provided by the WSL Swiss Federal Institute for Snow and Avalanche Research SLF (online: https://models.slf.ch/p/alpine3d/downloads/). Special thanks go to Michael Lehning and Mathias Bavay. Model forcing data are freely available online from the agencies listed in Table 1. The authors are grateful to everyone who provided field assistance, including Kevin Skeen, Scott Roberts, Bart Forman, Danielle Perrot, Ernesto Trujillo, Leah Meromy, Manuela Girotto, Annelen Kahl, Karl Rittger, Ned Bair, Dan Berisford, Alicia Kinoshita, and 
Matt Cooper.

Edited by: Ross Brown

Reviewed by: Brian Henn and Eric Sproles

\section{References}

Bales, R. C., Molotch, N. P., Painter, T. H., Dettinger, M. D., Rice, R., and Dozier, J.: Mountain hydrology of the western United States, Water Resour. Res., 42, W08432, https://doi.org/10.1029/2005WR004387, 2006.

Barnett, T. P. and Pierce, D. W.: Sustainable water deliveries from the Colorado River in a changing climate, P. Natl. Acad. Sci., 106, 7334-7338, 2009.

Barnett, T. P., Adam, J. C., and Lettenmaier, D. P.: Potential impacts of a warming climate on water availability in snow-dominated regions, Nature, 438, 303-309, 2005.

Barnhart, T. B., Molotch, N. P., Livneh, B., Harpold, A. A., Knowles, J. F., and Schneider, D.: Snowmelt rate dictates streamflow, Geophys. Res. Lett., 43, 8006-8016, 2016.

Bartelt, P. and Lehning, M.: A physical SNOWPACK model for the Swiss avalanche warning: Part I: numerical model, Cold Reg. Sci. Technol., 35, 123-145, 2002.

Bavay, M. and Egger, T.: MeteoIO 2.4.2: a preprocessing library for meteorological data, Geosci. Model Dev., 7, 3135-3151, https://doi.org/10.5194/gmd-7-3135-2014, 2014.

Bavay, M., Lehning, M., Jonas, T., and Löwe, H.: Simulations of future snow cover and discharge in Alpine headwater catchments, Hydrol. Process., 23, 95-108, 2009.

Bavay, M., Grünewald, T., and Lehning, M.: Response of snow cover and runoff to climate change in high Alpine catchments of Eastern Switzerland, Adv. Water Res., 55, 4-16, 2013.

Berghuijs, W., Woods, R., and Hrachowitz, M.: A precipitation shift from snow towards rain leads to a decrease in streamflow, Nat. Clim. Change, 4, 583-586, 2014.

Brown, R. D. and Mote, P. W.: The response of northern hemisphere snow cover to a changing climate*, J. Climate, 22, 2124-2145, 2009.

Cayan, D. R., Maurer, E. P., Dettinger, M. D., Tyree, M., and Hayhoe, K.: Climate change scenarios for the California region, Climatic change, 87, 21-42, 2008.

Christensen, L., Tague, C. L., and Baron, J. S.:, Spatial patterns of simulated transpiration response to climate variability in a snow dominated mountain ecosystem, Hydrol. Process., 22, 35763588, 2008.

Cooper, M. G., Nolin, A. W., and Safeeq, M.:Testing the recent snow drought as an analog for climate warming sensitivity of Cascades snowpacks, Environ. Res. Lett., 11, 084009, https://doi.org/10.1088/1748-9326/11/8/084009, 2016.

Dettinger, M.: Climate Change, Atmospheric Rivers, and Floods in California - A Multimodel Analysis of Storm Frequency and Magnitude Changes, J. Am. Water Resour. As., 47, 514-523, 2011.

Dettinger, M. D. and Cayan, D. R.: Large-scale atmospheric forcing of recent trends toward early snowmelt runoff in California, J. Climate, 8, 606-623, 1995.

Dettinger, M. D., Cayan, D. R., Meyer, M. K., and Jeton, A. E.: Simulated hydrologic responses to climate variations and change in the Merced, Carson, and American River basins, Sierra Nevada, California, 1900-2099, Clim. Change, 62, 283-317, 2004.

Eiriksson, D., Whitson, M., Luce, C. H., Marshall, H. P., Bradford, J., Benner, S. G., Black, T., Hetrick, H., and McNamara, J. P.:An evaluation of the hydrologic relevance of lateral flow in snow at hillslope and catchment scales, Hydrol. Process., 27, 640-654, 2013.

Elder, K., Dozier, J., and Michaelsen, J.: Spatial and temporal variation of net snow accumulation in a small alpine watershed, Emerald Lake basin, Sierra Nevada, California, USA, Ann. Glaciol., 13, 56-63, 1988.

Etchevers, P., Martin, E., Brown, R., Fierz, C., Lejeune, Y., Bazile, E., Boone, A., Dai, Y.-J., Essery, R., and Fernandez, A.: Validation of the energy budget of an alpine snowpack simulated by several snow models (SnowMIP project), Ann. Glaciol., 38, 150 $158,2004$.

Eyring, V., Bony, S., Meehl, G. A., Senior, C. A., Stevens, B., Stouffer, R. J., and Taylor, K. E.: Overview of the Coupled Model Intercomparison Project Phase 6 (CMIP6) experimental design and organization, Geosci. Model Dev., 9, 1937-1958, https://doi.org/10.5194/gmd-9-1937-2016, 2016.

Flerchinger, G., Xaio, W., Marks, D., Sauer, T., and Yu, Q.: Comparison of algorithms for incoming atmospheric long wave radiation, Water Resour. Res., 45, W03423, https://doi.org/10.1029/2008WR007394, 2009.

Fry, J. A., Xian, G., Jin, S., Dewitz, J. A., Homer, C. G., Limin, Y., Barnes, C. A., Herold, N. D., and Wickham, J. D.: Completion of the 2006 national land cover database for the conterminous United States, Photogr. Eng. Remote Sens., 77, 858-864, 2011.

Fyfe, J. C., Derksen, C., Mudryk, L., Flato, G. M., Santer, B. D., Swart, N. C., Molotch, N. P., Zhang, X., Wan, H., and Arora, V. K.: Large near-term projected snowpack loss over the western United States, Nature Commun., 8, 14996, https://doi.org/10.1038/ncomms14996, 2017.

Girotto, M., Margulis, S. A., and Durand, M.: Probabilistic SWE reanalysis as a generalization of deterministic SWE reconstruction techniques, Hydrol. Process., 28, 3875-3895, 2014a.

Girotto, M., Cortés, G., Margulis, S. A., and Durand, M.: Examining spatial and temporal variability in snow water equivalent using a 27 year reanalysis: Kern River watershed, Sierra Nevada, Water Resour. Res., 50, 6713-6734, 2014b.

Gleason, K. E., Nolin, A. W., and Roth, T. R.: Developing a representative snow-monitoring network in a forested mountain watershed, Hydrol. Earth Syst. Sci., 21, 1137-1147, https://doi.org/10.5194/hess-21-1137-2017, 2017.

Gleick, P. H.: The development and testing of a water balance model for climate impact assessment: modeling the Sacramento basin, Water Resour. Res., 23, 1049-1061, 1987.

Gleick, P. H. and Chalecki, E. L.: The impacts of climate changes for water resources of the Colorado and Sacramento-San Joaquin River basins, J. Am. Water Resour. As., 35, 1429-1441, 1999.

Godsey, S., Kirchner, J., and Tague, C.: Effects of changes in winter snowpacks on summer low flows: case studies in the Sierra Nevada, California, USA, Hydrol. Process., 28, 50485064, 2013.

Hamlet, A. F. and Lettenmaier, D. P.: Effects of 20th century warming and climate variability on flood risk in the western US, Water Resour. Res., 43, https://doi.org/10.1029/2006WR005099, 2007. 
Howat, I. M. and Tulaczyk, S.: Climate sensitivity of spring snowpack in the Sierra Nevada, J. Geophys. Res.-Earth Surface, 110, https://doi.org/10.1029/2005JF000356, 2005.

Hunsaker, C. T., Whitaker, T. W., and Bales, R. C.: Snowmelt runoff and water yield along elevation and temperature gradients in California's Southern Sierra Nevada1, edited, Wiley Online Library, 2012.

Huntington, J. L. and Niswonger, R. G.: Role of surface water and groundwater interactions on projected summertime streamflow in snow dominated regions: An integrated modeling approach, Water Resour. Res., 48, https://doi.org/10.1029/2012WR012319, 2012.

Jepsen, S. M., Molotch, N. P., Williams, M. W., Rittger, K. E., and Sickman, J. O.: Interannual variability of snowmelt in the Sierra Nevada and Rocky Mountains, United States: Examples from two alpine watersheds, Water Resour. Res., 48, https://doi.org/10.1029/2011WR011006, 2012.

Klein Tank, A., Zwiers, F. W., and Zhang, X.: Guidelines on analysis of extremes in a changing climate in support of informed decisions for adaptation, C. D. a. Monitoring, p. 56, World Meteorological Organization, 2009.

Knowles, N. and Cayan, D. R.: Potential effects of global warming on the Sacramento/San Joaquin watershed and the San Francisco estuary, Geophys. Res. Lett., 29, 38-31-38-34, 2002.

Knowles, N. and Cayan, D. R.: Elevational dependence of projected hydrologic changes in the San Francisco estuary and watershed, Clim. Change, 62, 319-336, 2004.

Knowles, N., Dettinger, M. D., and Cayan, D. R.: Trends in Snowfall versus Rainfall in the Western United States, J. Climate, 19, 4545-4559, 2006.

Kobierska, F., Jonas, T., Magnusson, J., Zappa, M., Bavay, M., Bosshard,, T., Paul, F., and Bernasconi, S. M.: Climate change effects on snow melt and discharge of a partly glacierized watershed in Central Switzerland (SoilTrec Critical Zone Observatory), Appl. Geochem., 26, Supplement, S60-S62, 2011.

Kobierska, F., Jonas, T., Zappa, M., Bavay, M., Magnusson, J., and Bernasconi, S. M.: Future runoff from a partly glacierized watershed in Central Switzerland: a two-model approach, Adv. Water Res., 55, 204-214, 2013.

Lehning, M., Völksch, I., Gustafsson, D., Nguyen, T. A., Stähli, M., and Zappa, M.: ALPINE3D: a detailed model of mountain surface processes and its application to snow hydrology, Hydrol. Process., 20, 2111-2128, 2006.

Letcher, T. W. and Minder, J. R.: Characterization of the Simulated Regional Snow Albedo Feedback Using a Regional Climate Model over Complex Terrain, J. Climate, 28, 7576-7595, 2015.

Lettenmaier, D. P. and Gan, T. Y.: Hydrologic sensitivities of the Sacramento San Joaquin River Basin, California, to global warming, Water Resour. Res., 26, 69-86, 1990.

Lettenmaier, D. P., Wood, A. W., Palmer, R. N., Wood, E. F., and Stakhiv, E. Z.: Water resources implications of global warming: A US regional perspective, Climatic Change, 43, 537-579, 1999.

Liston, G. E. and Elder, K.: A Meteorological Distribution System for High-Resolution Terrestrial Modeling (MicroMet), J. Hydrometeorol., 7, 217-234, 2006.

Liu, C., Ikeda, K., Rasmussen, R., Barlage, M., Newman, A. J., Prein, A. F., Chen, F., Chen, L., Clark, M., and Dai, A.: Continental-scale convection-permitting modeling of the current and future climate of North America, Clim. Dynam., 49, 71-95, https://doi.org/10.1007/s00382-016-3327-9, 2017.

López-Moreno, J. I., Fassnacht, S., Heath, J., Musselman, K., Revuelto, J., Latron, J., Morán-Tejeda, E., and Jonas, T.: Small scale spatial variability of snow density and depth over complex alpine terrain: Implications for estimating snow water equivalent, Adv. Water Res., 55, 40-52, 2013.

López-Moreno, J. I., Mott, R., Faure, F., Lehning, M., Löwe, H., Hynek, B., Michlmayer, G., Prokop, A., and Schöner, W.: Different sensitivities of snowpacks to warming in Mediterranean climate mountain areas, Environ. Res. Lett., 49, 155-160, 2017.

Luce, C. H. and Holden, Z. A.: Declining annual streamflow distributions in the Pacific Northwest United States, 1948-2006, Geophys. Res. Lett., 36, https://doi.org/10.1029/2009GL039407, 2009.

Lundquist, J. D. and Loheide, S. P.: How evaporative water losses vary between wet and dry water years as a function of elevation in the Sierra Nevada, California, and critical factors for modeling, Water Resour. Res., 47, https://doi.org/10.1029/2010WR010050, 2011.

Magnusson, J., Farinotti, D., Jonas, T., and Bavay, M.: Quantitative evaluation of different hydrological modelling approaches in a partly glacierized Swiss watershed, Hydrol. Process., 25, 20712084, 2011.

Margulis, S. A., Cortés, G., Girotto, M., and Durand, M.: A Landsat-Era Sierra Nevada Snow Reanalysis (1985-2015), J. Hydrometeorol., 17, 1203-1221, 2016.

Marks, D. and Dozier, J.: Climate and energy exchange at the snow surface in the alpine region of the Sierra Nevada: 2. Snow cover energy balance, Water Resour. Res., 28, 3043-3054, 1992.

Marks, D., Dozier, J., and Davis, R. E.: Climate and energy exchange at the snow surface in the Alpine Region of the Sierra Nevada: 1. Meteorological measurements and monitoring, Water Resour. Res., 28, 3029-3042, 1992.

Marty, C., Schlögl, S., Bavay, M., and Lehning, M.: How much can we save? Impact of different emission scenarios on future snow cover in the Alps, The Cryosphere, 11, 517-529, https://doi.org/10.5194/tc-11-517-2017, 2017.

McCabe, G. J. and Clark, M. P.: Trends and variability in snowmelt runoff in the western United States, J. Hydrometeorol., 6, 476482, 2005.

Michlmayr, G., Lehning, M., Koboltschnig, G., Holzmann, H., Zappa, M., Mott, R., and Schöner, W.: Application of the Alpine 3D model for glacier mass balance and glacier runoff studies at Goldbergkees, Austria, Hydrol. Process., 22, 3941-3949, 2008.

Minder, J. R.: The Sensitivity of Mountain Snowpack Accumulation to Climate Warming, J. Climate, 23, 2634-2650, 2010.

Molotch, N., Colee, M., Bales, R., and Dozier, J.: Estimating the spatial distribution of snow water equivalent in an alpine basin using binary regression tree models: the impact of digital elevation data and independent variable selection, Hydrol. Process., 19, 1459-1479, 2005.

Molotch, N. P. and Meromy, L.: Physiographic and climatic controls on snow cover persistence in the Sierra Nevada Mountains, Hydrol. Process., 28, 4573-4586, 2014.

Molotch, N. P., Blanken, P. D., Williams, M. W., Turnipseed, A. A., Monson, R. K., and Margulis, S. A.: Estimating sublimation of intercepted and sub-canopy snow using eddy covariance systems, Hydrol. Process., 21, 1567-1575, 2007. 
Mote, P. W., Hamlet, A. F., Clark, M. P., and Lettenmaier, D.: Declining mountain snowpack in western North America, B. Am. Meteorol. Soc., 86, 39-49, 2005.

Mott, R., Faure, F., Lehning, M., Löwe, H., Hynek, B., Michlmayer, G., Prokop, A., and Schöner, W.: Simulation of seasonal snowcover distribution for glacierized sites on Sonnblick, Austria, with the Alpine3D model, Ann. Glaciol., 49, 155-160, 2008.

Musselman, K. N., Molotch, N. P., Margulis, S. A., Lehning, M., and Gustafsson, D.: Improved snowmelt simulations with a canopy model forced with photo-derived direct beam canopy transmissivity, Water Resour. Res., 48, https://doi.org/10.1029/2012WR012285, 2012a.

Musselman, K. N., Molotch, N. P., Margulis, S. A., Kirchner, P., and Bales, R. C.: Influence of canopy structure and direct beam solar irradiance on snowmelt rates in a mixed conifer forest, Agr. Forest Meteorol., 161C, 46-56, 2012b.

Musselman, K. N., Pomeroy, J. W., Essery, R. L., and Leroux, N.: Impact of windflow calculations on simulations of alpine snow accumulation, redistribution and ablation, Hydrol. Process., 29, 3983-3999, 2015.

Musselman, K. N., Clark, M. P., Liu, C., Ikeda, K., and Rasmussen, R.: Slower snowmelt in a warmer world, Nature Clim. Change, 7, 214-219, 2017.

Nolin, A. W. and Daly, C.: Mapping "at risk" snow in the Pacific Northwest, J. Hydrometeorol., 7, 1164-1171, 2006.

National Park Service: Sequoia and Kings Canyon Weather. National Park Service, U.S. Department of the Interior, 5 January 2017, available at: https://www.nps.gov/seki/planyourvisit/ weather.htm, last access: 7 July 2017.

Penna, D., Tromp-van Meerveld, H. J., Gobbi, A., Borga, M., and Dalla Fontana, G.: The influence of soil moisture on threshold runoff generation processes in an alpine headwater catchment, Hydrol. Earth Syst. Sci., 15, 689-702, https://doi.org/10.5194/hess-15-689-2011, 2011.

Pepin, N. and Lundquist, J.: Temperature trends at high elevations: patterns across the globe, Geophys. Res. Lett., 35, https://doi.org/10.1029/2008GL034026, 2008.

Perrot, D., Molotch, N. P., Williams, M. W., Jepsen, S. M., and Sickman, J. O.: Relationships between stream nitrate concentration and spatially distributed snowmelt in high elevation catchments of the western US, Water Resour. Res., 50, 8694-8713, 2014.

Prein, A. F., Rasmussen, R. M., Ikeda, K., Liu, C., Clark, M. P., and Holland, G. J.: The future intensification of hourly precipitation extremes, Nature Clim. Change, 7, 48-52, https://doi.org/10.1038/nclimate3168, 2016.

Rasouli, K., Pomeroy, J. W., and Marks, D. G.: Snowpack sensitivity to perturbed climate in a cool mid latitude mountain catchment, Hydrol. Process., 29, 3925-3940, 2015.

Rice, R., Bales, R. C., Painter, T. H., and Dozier, J.: Snow water equivalent along elevation gradients in the Merced and Tuolumne River basins of the Sierra Nevada, Water Resour. Res., 47, https://doi.org/10.1029/2010WR009278, 2011.

Rutter, N., Essery, R., Pomeroy, J., et al.: Evaluation of forest snow processes models (SnowMIP2), J. Geophys. Res.-Atmos., 114, https://doi.org/10.1029/2008JD011063, 2009.

Schlögl, S., Marty, C., Bavay, M., and Lehning, M.: Sensitivity of Alpine3D modeled snow cover to modifications in DEM resolution, station coverage and meteorological input quantities, Environ. Model. Softw., 83, 387-396, 2016.
Seager, R., Ting, M., Li, C., Naik, N., Cook, B., Nakamura, J., and Liu, H.: Projections of declining surface-water availability for the southwestern United States, Nature Clim. Change, 3, 482-486, 2013.

Sexstone, G. A., Clow, D. W., Stannard, D. I., and Fassnacht, S. R.: Comparison of methods for quantifying surface sublimation over seasonally snow covered terrain, Hydrol. Process., 30, 33733389, 2016.

Sickman, J. O., Leydecker, A., Chang, C. C., Kendall, C., Melack, J. M., Lucero, D. M., and Schimel, J.: Mechanisms underlying export of $\mathrm{N}$ from high-elevation catchments during seasonal transitions, Biogeochemistry, 64, 1-24, 2003.

Sproles, E. A., Roth, T. R., and Nolin, A. W.: Future snow? A spatial-probabilistic assessment of the extraordinarily low snowpacks of 2014 and 2015 in the Oregon Cascades, The Cryosphere, 11, 331-341, https://doi.org/10.5194/tc-11-3312017, 2017.

Stewart, I. T., Cayan, D. R., and Dettinger, M. D.: Changes in snowmelt runoff timing in western North America under abusiness as usual climate change scenario, Climatic Change, 62, 217232, 2004.

Stocker, T. F., Qin, D., Plattner, G.-K., Tignor, M., Allen, S. K., Boschung, J., Nauels, A., Xia, Y., Bex, V., and Midgley, P. M.: Climate Change 2013. The Physical Science Basis. Working Group I Contribution to the Fifth Assessment Report of the Intergovernmental Panel on Climate Change-Abstract for decisionmakers, Groupe d'experts intergouvernemental sur l'evolution du climat/Intergovernmental Panel on Climate Change-IPCC, C/O World Meteorological Organization, 7bis Avenue de la Paix, CP 2300 CH-1211 Geneva 2 (Switzerland), 2013.

Sturm, M., Goldstein, M. A., and Parr, C.: Water and life from snow: A trillion dollar science question, Water Resour. Res., 53, 35343544, https://doi.org/10.1002/2017WR020840, 2017.

Sun, F., Hall, A., Schwartz, M., Walton, D. B., and Berg, N.: Twenty-First-Century Snowfall and Snowpack Changes over the Southern California Mountains, J. Climate, 29, 91-110, 2016.

Tague, C. and Peng, H.: The sensitivity of forest water use to the timing of precipitation and snowmelt recharge in the California Sierra: Implications for a warming climate, J. Geophys. Res.Biogeosc., 118, 875-887, 2013.

Tague, C., Grant, G., Farrell, M., Choate, J., and Jefferson, A.: Deep groundwater mediates streamflow response to climate warming in the Oregon Cascades, Climatic Change, 86, 189-210, 2008.

Tonnessen, K. A.: The Emerald Lake watershed study: introduction and site description, Water Resour. Res., 27, 1537-1539, 1991.

Trenberth, K. E.: Changes in precipitation with climate change, Clim. Res., 47, 123-138, 2011.

Trujillo, E. and Molotch, N. P.: Snowpack regimes of the Western United States, Water Resour. Res., 50, 5611-5623, 2014.

Trujillo, E. and Lehning, M.: Theoretical analysis of errors when estimating snow distribution through point measurements, The Cryosphere, 9, 1249-1264, https://doi.org/10.5194/tc-9-12492015, 2015.

Trujillo, E., Molotch, N. P., Goulden, M. L., Kelly, A. E., and Bales, R. C.: Elevation-dependent influence of snow accumulation on forest greening, Nature Geosci., 5, 705-709, 2012.

Vano, J. A., Udall, B., Cayan, D. R., Overpeck, J. T., Brekke, L. D., Das, T., Hartmann, H. C., Hidalgo, H. G., Hoerling, M., and 
McCabe, G. J.: Understanding uncertainties in future Colorado River streamflow, B. Am. Meteorol. Soc., 95, 59-78, 2014.

van Oldenborgh, G. J., Collins, M., Arblaster, J., Christensen, J. H., Marotzke, J., Power, S. B., Rummukainen, M., and Zhou, T. (Eds.): Annex I: Atlas of global and regional climate projections supplementary material RCP8.5. Climate Change 2013: The Physical Science Basis, edited by: Stocker, T. F. et al., Cambridge University Press, AISM-1-AISM-159, available at: www.climatechange2013.org/images/report/WG1AR5 AISM8.5_FINAL.pdf, 2013.
West, A. J. and Knoerr, K. R.: Water losses in the Sierra Nevada, J. Am. Water Works Assoc., 51, 481-488, 1959.

Williams, M. W. and Melack, J. M.: Solute chemistry of snowmelt and runoff in an alpine basin, Sierra Nevada, Water Resour. Res., 27, 1575-1588, 1991.

Winchell, T. S., Barnard, D. M., Monson, R. K., Burns, S. P., and Molotch, N. P.: Earlier snowmelt reduces atmospheric carbon uptake in midlatitude subalpine forests, Geophys. Res. Lett., 43, 8160-8168, 2016. 